\title{
WestVirginiaUniversity
}

THE RESEARCH REPOSITORY @ WVU

West Virginia Agricultural and Forestry Experiment

Davis College of Agriculture, Natural Resources

Station Bulletins

And Design

$1-1-1928$

\section{A study of correlated inheritance in a certain Avena cross}

Ralph John Garber

Karl S. Quisenberry

Follow this and additional works at: https://researchrepository.wvu.edu/ wv_agricultural_and_forestry_experiment_station_bulletins

\section{Digital Commons Citation}

Garber, Ralph John and Quisenberry, Karl S., "A study of correlated inheritance in a certain Avena cross" (1928). West Virginia Agricultural and Forestry Experiment Station Bulletins. 217.

https://researchrepository.wvu.edu/wv_agricultural_and_forestry_experiment_station_bulletins/217 @ WVU. It has been accepted for inclusion in West Virginia Agricultural and Forestry Experiment Station Bulletins by an authorized administrator of The Research Repository @ WVU. For more information, please contact ian.harmon@mail.wvu.edu. 
West Virginia University Libraries 


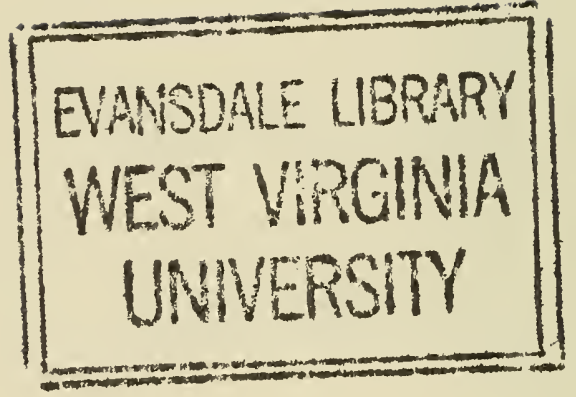




\section{Restricted}

\section{Circulation Only}

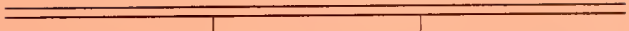





\section{Angrialtural Fixpriment Statim}

College of Agriculture, West Virginia University

N. J. Giddings, Acting Director

Morgantown

Study of Correlated Inheritance in a Certain Avena Cross

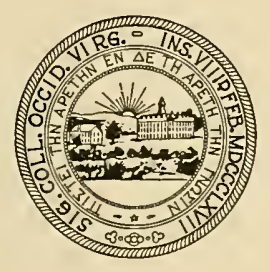

By

R. J. GARBER and K. S. QUISENBERRY

Publications of this Station will be mailed free to any citizen of West Virginia written application. Address Director of the West Virginia Agricultural ExperiStation, Morgantown, West Virginia. 


\section{AGRICULTURAL EXPERIMENT STATION STAFF}

FRANK BUTLER TROTTER, A. M., LL. D.

President of the Univ N. J. GIDDINGS, Ph. D Acting Dean and $\mathrm{D}$

WAL'S'ER C. SCHNOPP, B. S. Agr Agricultural

JOHN C. JOHNSTON Chief

\section{AGRONIMY AND GENETICS}

R. J. Garber, Ph. D. Agronomist and Geneticist

E. P. Deatrick. Ph. D. Associate Agronomist (Soils)

T. E. Odland, l'h. D.

Associate Agronomist

T. C. McIlvaine, Ph. D. $\dagger$ Assistant Agronomist (Soils)

D. R. Dodd, M. S.

M. M. Hoover, M. S

Assistant Agronomist

H. I. Rowley, M. S. Agr.**

Seed Analyst

\section{ANIMAL HUSBANDRY}

E. A. Livesay, M. S.

Animal Husbandman

Chas. V. Wilson, M. S.

Assistant Animal Husbandman

J. H. Longwell, M. A.

Assistant Animal Husbandman

J. H. Rietz, D. V. M.

Associate Veterinarian

R. H. Tuckwiller, B. S. Agr.*

Assistant Animal Husbandman

\section{CHEMISTRY}

R. B. Dustman, Ph. D.

Associate Chemist

Chas. E. Weakley, Jr., B. A.

Assistant Chemist

L. P. Hansen, Ph. D.

T. B. Leith, B. A.**

Assistant Chemist

Assistant Chemist

Leland Shriver

Assistant in Chemistry

\section{DAIRY HUSBANDRY}

E. L. Anthony, M. S. Agr.

Dairy Husbandman

H. O. Henderson, M. S. Agr.

Associale Dairy Husbandman

G. Malcolm Trout, M. S.

Assistant Dairy Husbandman

ENTOMOLOGY

L. M. Peair's, Ph. D.

L. E. Dills, M. $S . * *$

State Entomologist

Assistant in Entomology
FARM ECONOMICS

A. J. Dadisman, Ph. D.

Paul A. Eke, Ph. D.

Assistant Farm Ecor

F. D. Cornell, Jr., M. S.

Junior Farm Mecha

W. W. Armentrout, M. S.

Junior Farm Ecor

HOME ECONOMICS

Rachel H. Colwell, A. M.

Home Ecor

Hazel C. Cameron, M. S.

Research Specialist in

Nell Nesbitt, A. M.

Research Specialist in Home

HORTICULTURE

H. E. Knowlton, Ph. D.

Associate Horticul $r$

H. L. Crane, M. S. Agr.

Associate Horlicul

K. C. Westover, M. S. Agr.

Assistant Horlicul

Ernest Angelo, M. S. Agr. Junior Horl.icu]

L. F. Sutton, B. S. Agr.\$ Assistant Horlicul

H. P. Sevy, M. S. Agr. Assistant in Hortici.

M. B. Hoffman, M. S. Assistant in JJorlicu

PLANT PATHOLOGY

N. J. Giddings, $\mathrm{Ph}$. D.

Anthony Berg, M. S. Associate Plant Patho

L. H. Leonian, Ph. D. Associate Plant Palho

E. C. Sherwood, M. S. Assistant Plant Palho

\section{POULTRY HUSBANDRY}

Horace Atwood, M.S. Agr. Poultry Fussane

E. T. Wightman, M. S. Agr. Junior Poultry Husluarıa

RURAL SOCIOLOGY

T. L. Harris, Ph. D.

Rural Sociol is

\section{ZOOLOGY}

F. E. Chidester, Ph. D.

Zool

*In cooperation with the U. S. Department of Agriculture, Washington, D.

in charge of the Lakin Sub-station, Lakin, W. Va.

**In cooperation with the State Department of Agriculture, Charleston, W. Ve

$\ddagger$ In charge of the Reymann Memorial Farms, Wardensville, W. Va. 


\section{TABLE OF CONTENTS}

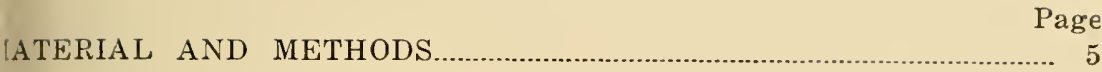

VHERITANCE OF DATE OF HEADING ……............................................. 7

Preliminary Observations.................................................................... 7

Environmental Influence......................................................................... 8

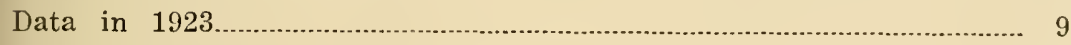

Data in 1924

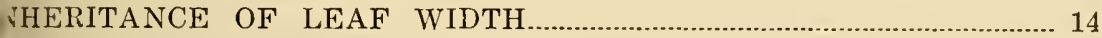

Preliminary Observations....................................................................... 14

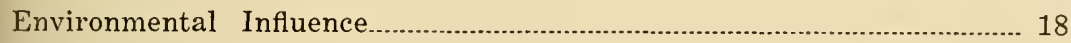

Data in 1923

Data in 1924

IHERITANCE OF NUMBER OF CULMS................................................ 25

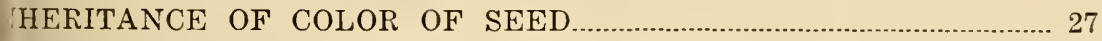

TERRELATION OF HERITABLE CHARACTERS._._........................... 27

Seed Color and Other Characters.............................................................. 28

Leaf Width and Number of Culms

Leaf Width and Date of Heading........................................................... 31

Date of Heading and Number of Culms _.................................................... 32

MMARY AND CONCLUSIONS................................................................... 33

'PENDIX 



\section{A Study of Correlated Inheritance in a Certain Avena Cross*}

The inheritance of quantitative characters is of particular interest $n$ the plant breeder engaged in an attempt to produce superior ecoomic plants. More detailed information concerning the manner of ransmission of size characters in our common erop plants is needed 0 aid in accomplishing crop improvement. It was with the hope of ontributing something to our present knowledge that a number of ize inheritance studies in oats were planned a few years' ago. The csults of two of these studies have been published in recent bulletins $f$ this station. $\dagger$ A review of the literature pertaining to the inseritance of quantitative characters in oats may be found in these mlletins and also in a recent publication of the Pennsylvania Agriculural Experiment Station.t

The parent plants, a few $F_{1}$ plants, and a considerable number of he $\mathrm{F}_{2}$ and the $\mathrm{F}_{3}$ generations of Avena sativa used for this study were rown in the plant breeding nursery at Morgantown in 1923. The ross was first made in 1921 for the purpose of studying the inheritance $f$ resistance to smut and continued as such for three years, but the mut epidemic failed to materialize, and since the parents of the cross iffered with respect to a number of characters, it was decided to use he material for an inheritance study of these characters.

\section{MATERIAL AND IIETHODS}

The parents of the progeny, whose breeding behavior is described 1 the following pages, were single panicle selections made from the arieties Black Mesdag and Gopher. Black Mesdag is a midseason at, highly resistant to oat smut, with black seed and stiff culms. It as somewhat broader leaves than Gopher and is inclined to develop wer elums per plant.

Gopher, a pure line selection made at the Minnesota Agrieultural ixperiment Station from the variety "Sixty Day," is an earlylaturing, white-seeded strain with an exceptionally stiff straw. It as a somewhat coarser appearance than Sixty Day, and also has

*Submitted for publication May, 1926.

TQUISEnBERrX, K. S. Correlated Inheritance of Quantitative and Qualitative haracters in Oats. W. Va. Agr. Exp. Sta. Bul. 202. 1925.

TOdLAND, T. E. The Inheritance of Rachilla Length and Its Relation to Other haracters in a Cross Between Avena Sativa and Avena Orientalis. W. Va. Agr. xp. Sta. Bul. 219, April, 1928 .

Noll, C. F. Studies of Inheritance of Earliness in Certain Arena Crosses. Pa. gr. Exp. Sta. Bul. 194. 1925. 
greater awn development under the environmental conditions Morgantown. It is one of the highest yielding varieties of oats' th have been grown on the Agronomy Farm at Morgantown.

These varieties were crossed in the greenhouse, and in 1921, small $\mathrm{F}_{1}$ generation was grown. An $\mathrm{F}_{2}$ generation was grown in 19 but $n o$ notes were taken on the characters discussed in this bullet until 1923, when a considerable number of $\mathrm{F}_{2}$ and $\mathrm{F}_{3}$ families was ava able. In addition, a few $F_{1}$ plants and the parents, all grown und similar conditions, were also available during this year.

Just previous to the planting of this material, the seed $\mathrm{w}$ treated with smut, but, owing apparently to the adverse conditio for the development of the fungus, very few plants of the susceptib parent became infected. In view of this fact it was decided to use t] plants for a study of the inheritance of leaf width, number of culn date of heading, and color of seed in their relation to one anothe The study was continued in 1924 when the seed was not treated wi smut and somewhat larger $\mathrm{F}_{3}$ families were grown.

In 1923 the parents and the progeny were grown in rows eig. feet long and one foot apart, with 35 seeds spaced approximate three inches apart in each row. It was necessary to fill out some ror with bulk seed, the plants from which were discarded later. Tl plants growing next to the borders were not considered, owing to tl obvious border influence on development. In 1924 the material w: grown in rows five feet long and one foot apart, the 25 seeds plant per row being spaced at approximately equal distances. Two ind vidually spaced seeds of the Gopher parent were planted at eac end of the rows to prevent border influence on the experimental plant but were pulled and discarded just previous to heading. The paren were grown every twelfth row among the $\mathrm{F}_{3}$ families in 1923 and $\mathrm{i}$ 1924. The parents were also grown with the $\mathrm{F}_{2}$ generations. I 1923 the parents and $\mathrm{F}_{3}$ families' were grown in single-row plots br in 1924 they were grown in two-row plots.

Practically all the notes were taken in the field. Heading note were taken every other day and a plant was considered headed whe all the spikelets had emerged from the boot on the main culm. Lea widths were determined by measuring in millimeters the width of th second leaf (from the top down) at the widest part, which is rele tively near the juncture of the blade with the sheath. The measur ments' were taken after the plants were headed, but before the leave became dry. The number of culms and color of the seed were ascer tained at harvest after the plants had matured. Individual plant dat 
are taken on part of the parents and on the $F_{1}$ and $F_{2}$ generations own in 1923 and on all the material grown in 1924. Number of Ims and leaf widths were obtained on the $F_{3}$ families grown in 23, but no attempt was made to keep the notes of individual plants parate.

The soil on which the plants were grown was a DeKalb silt loam medium produetivity. It will be shown later that the plot series ed in these experiments were not as uniform as was desirable.

\section{INHERITANCE OF DATE OF HEADING Preliminary Observations}

In order to obtain some idea of the number of $\mathrm{F}_{2}$ plants grown in -4 necessary to constitute a random sample, the variability of the io $\mathrm{F}_{2}$ families with respect to date of heading was studied. One of ise families had 308 individuals and the other had 314 . It so hapined that one family was grown on an inferior plot and consequently t? mean date of heading of the plants on this plot was different from 12 mean date of heading of the $\mathrm{F}_{2}$ family on the other plot. For this Inson the data from the two families were kept separate.

In Table 1 are shown the frequency distributions of the mean te of hearling based on different random samples taken from the $F_{2}$ ceration. It will be noted that on the average the 16-Family headed newhat earlier than the 17-Family. In both families, it may be s 11 that 62 individuals chosen at random eonstituted a fairly trustrthy sample from which to ealeulate a mean. In the ease of the 1 Family, 30 individuals taken at random gave a fairly trustworthy iple. The mean dates of heading of the ten samples, each made II of 30 individuals, fall into two classes.

TBLE I.-Frequency Distributions for the Mean Dates of Heading Based on Different Samples Taken from the $\mathrm{F}_{2}$ Generation of Gopher $\times$ Black Mesdag and the Reciprocal Grown in 1924.

\begin{tabular}{|c|c|c|c|c|c|c|c|c|}
\hline \multirow{2}{*}{ Kind of Sample } & \multirow{2}{*}{$n$} & \multicolumn{7}{|c|}{ Mean Dates of Heading ${ }^{*}$} \\
\hline & & 7.25 & 7.75 & 8.25 & 8.75 & 9.25 & 9.75 & 10.25 \\
\hline 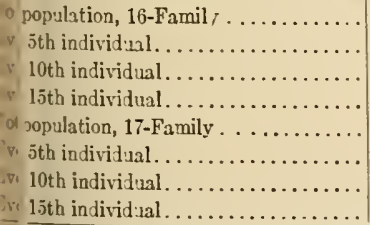 & $\begin{array}{l}62 \\
30 \\
20 \\
62 \\
33 \\
27\end{array}$ & $\begin{array}{l}2 \\
4\end{array}$ & $\begin{array}{l}1 \\
4 \\
1 \\
4\end{array}$ & $\begin{array}{l}1 \\
5 \\
4\end{array}$ & $\begin{array}{l}2 \\
3\end{array}$ & $\begin{array}{l}1 \\
4 \\
5 \\
4\end{array}$ & $\begin{array}{l}1 \\
5 \\
7\end{array}$ & 2 \\
\hline
\end{tabular}

he date of heading of the first $\mathrm{F}_{2}$, plant was considered as 1 , and the man dates given hare are in tarns of days. 
TABLE 2.-Frequency Distributions for the Standard Deviations of Dates Heading Based on Different Samples Taken From the $\mathbf{F}_{2}$ Gent tion of Gopher $\times$ Black Mesdag and the Reciprocal Grown 1924.

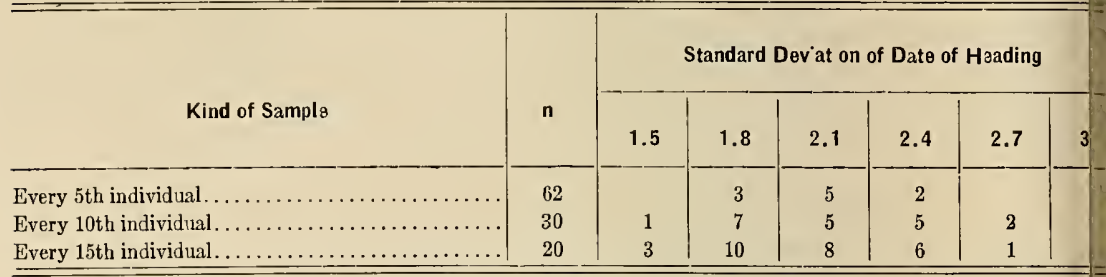

The frequency distributions of the standard deviations based $n$ the same random samples as previously discussed are shown in Tale 2. Since no appreciable difference was discerned between the tributions from the two families, they were combined in the table. Ie range of the standard deviations of date of heading of the ten rando samples, each made up of 62 individuals, was from 1.8 to 2.4, inc:sive. It is apparent from Table 2 that 20 or 30 individuals were t enough to constitute a very trustworthy sample from which to cal late a standard deviation.

There were approximately forty individuals in each $\mathrm{F}_{3}$ fam grown in 1924.

\section{Environmental Influence}

Before taking up the discussion of the inheritance of date heading it may be well to point out the possible non-genetic influese on the development of this character. In 1924 the correlation betw the mean date of heading of consecutive plots of the parents grow with the $\mathrm{F}_{3}$ families was determined and also the correlation betwi the means of the date of heading of the two different parents grow in adjacent plots. If a marked influence of soil on date of headi? existed, the correlation coefficients should show it. The correlat 1 between mean date of heading and number of plants per plot $\mathrm{ys}^{\mathrm{S}}$ also determined for each parental plot. The data are presented Table 3.

TABLE 3.-Correlation Coefficients That Show the Effect of Environment Date of Heading in the Oat Parents Grown in 1924.

\begin{tabular}{c|c|c}
$\mathbf{n}$ & $\boldsymbol{r}$ \\
\hline. & 27 & $+0.372 \pm 1$ \\
27 & $+0.429 \pm$ \\
31 & $+0.712 \pm$ \\
31 & $-0.679 \pm$ \\
31 & $-0.030 \pm$
\end{tabular}


The correlation eofficient between the mean dates of heacling in iseentive plots of Gopher is $+0.372 \pm 0.112$, and in eonseeutive ts of Black Mesdag $+0.429 \pm 0.106$. These faets and the relatively h eorrelation $(+0.712 \pm 0.060)$ obtained between the mean rlates of uling of the two parents growing in adjacent plots indicate that the I medium in which the plants grew had a rather marked influenee date of heading.

The number of plants per plot in the Gopher parent was negaely correlated $(-0.679 \pm 0.065)$ with the date of heading but in Black Mesdag parent no such relationship was found. In this case relation $(-0.090 \pm 0.120)$ was sensibly zero.

In addition to the environmental factors already mentioned, season I time of planting may influence the date of heading. In 1923 the l'erenee between the mean dates of heading for the two parents was ut two weeks, whereas in 1924 the difference was approximately week.

\section{Data In 1923}

Individual plant notes were taken on the $F_{1}$ and $F_{2}$ plants in is only. The mean date of heading of each parental plot was estiited. 'The approximate mean date of heading of each of the two ts of Gopher growing with the first and second generation plants sune 18 and for each of the two plots of Black Mesdag July 1, an imater differenee between the parents of 13 days. There was no Helenee between the date of heading of the two $F_{1}$ plants of Gopher Black Mesdag and the four $\mathrm{F}_{1}$ plants of the reciprocal eross. The an date of heading of the six $F_{1}$ plants was June 16 or approxitely the same as the early maturing parent. This is in agreement h the behavior of some of the $\mathrm{F}_{1}$ generations reported by Noll.*

the $\mathrm{F}_{2}$ generation slowed considerable variability with respect to le of heading as was expected. The frequency distribution is shown Table 4. The range of date of heading is from the early parent to I BLE 4.-Frequency Distribution of the Dates of Heading for the $F_{2}$ Generation of Gopher $\times$ Black Mesdag and the Reciprocal Grown in 1923.

\begin{tabular}{|c|c|c|c|c|c|c|c|c|c|c|c|}
\hline \multirow{2}{*}{ Name of Strain } & \multicolumn{11}{|c|}{ Dates of Heading $\uparrow$} \\
\hline & $6 / 16$ & $6 / 18$ & $6 / 20$ & $6 / 22$ & $6 / 24$ & $6 / 26$ & $6 / 28$ & $6 / 30$ & $7 / 2$ & $7 / 4$ & n \\
\hline ler X Black Mesdag \& Reciprocal. & 60 & 58 & 29 & 44 & 59 & 116 & 67 & 21 & 0 & 1 & 455 \\
\hline
\end{tabular}


the late parent and shows clearly that segregation has occurred. is apparent, too, that there were more $\mathrm{F}_{2}$ plants with a date of heac similar to that of the early parent (June 18) than there were to of the late parent (July 1).

\section{Data In 1924}

Notes were taken on each individual plant for all the mate grown in 1924. The difference between the average date of heacle for the two parents was approximately one-half of what it wasir 1923 owing, undoubtedly, to environmental influence. The freque distributions of the $\mathrm{F}_{2}$ generation and the parents which were grc with it are shown in Table 5 . There were $308 \mathrm{~F}_{2}$ plants of Gophes Black Mesdag and $314 \mathrm{~F}_{2}$ plants of the reciprocal cross. The dif $\mathrm{r}$ ence between the mean dates of heading of the two $\mathrm{F}_{2}$ families $1.51 \pm 0.11$, which is significant in the light of its probable error. of the $\mathrm{F}_{2}$ families, unfortunately, was planted on an inferior jt which fact probably accounts for the difference obtained.

It is evident from Table 5 that segregation for date of headie occurred in the $\mathrm{F}_{2}$ generation. The mode of the $\mathrm{F}_{2}$ generation consir $\mathrm{r}$ ing both families together corresponds to the mode of the Gop parent. The $\mathrm{F}_{2}$ distributions clearly indicate that earliness is inher: as a dominant character. In 1924 the two parents overlapped so what in date of heading. The variability of the late parent, as in cated by the standard deviation, is practically the same as that of te earlier parent. The means for dates of lheading of the $\mathrm{F}_{2}$ families much nearer to the mean of the Gopher parent than to the mean of tie Black Mesdag parent.

That date of heading is a definitely inherited character mayre further shown by correlating the date of heading of individual ? plants with the mean date of heading of their $F_{3}$ progeny. Jis has been done in Table 6 . The correlation coefficient obtained $+0.401 \pm 0.046$, which indicates that there was a tendency for $\mathrm{F}_{2}$ plols to transmit date of heading to their respective $\mathrm{F}_{3}$ families.

The frequency distributions of the mean dates of heading of the $\mathrm{T}_{3}$ families and the parents grown with them are shown in Table 7.

The mean date of heading of each of five of the $\mathrm{F}_{3}$ families earlier than the mean date of heading of the earliest plot of Goplr. On the other hand there were four plots of Black Mesdag with $\mathrm{m}$ dates of heading later than the mean date of heading of the latest? 


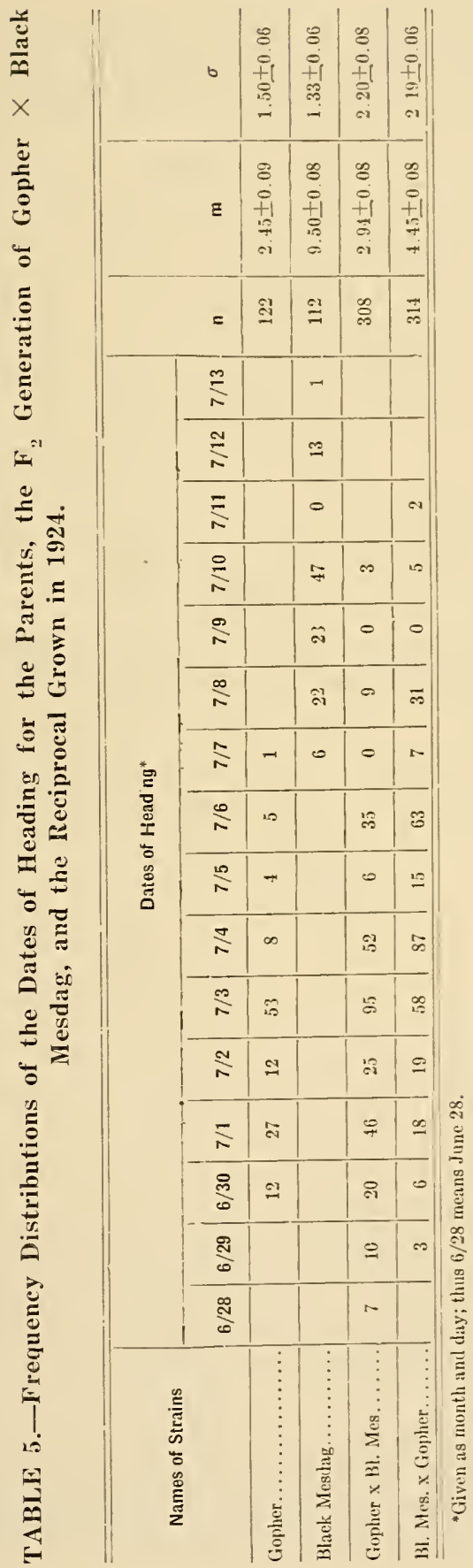


TABLE 6.-Correlation Between Date of Heading of Individual Plants in and the Mean Date of Heading of Their $\mathrm{F}_{3}$ Progeny in the $\mathrm{Cr}$ Gopher $\times$ Black Mesdag and the Reciprocal.

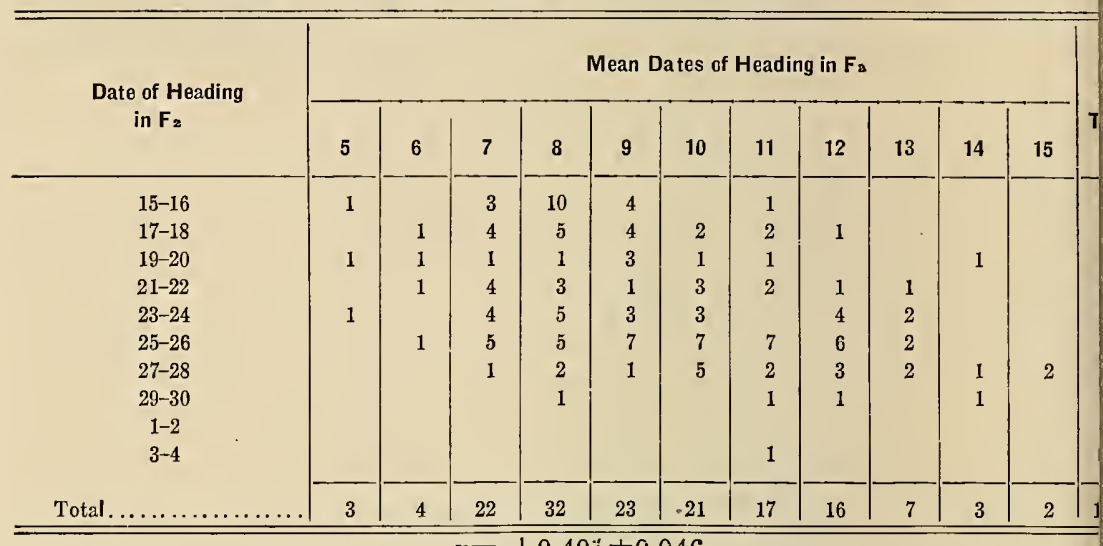

TABLE 7.-The Mean Dates of Heading for the $F_{3}$ Families and the Pare of the Cross Gopher $\times$ Black Mesdag and the Reciprocal Gron in 1924.

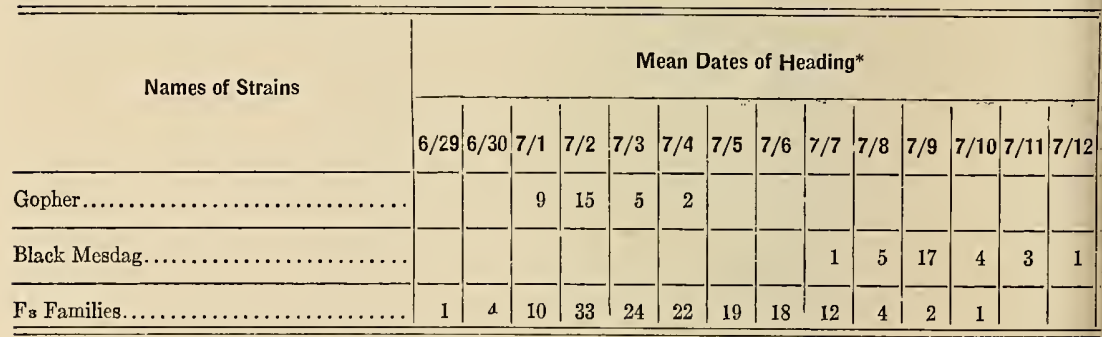

*Given as month and day; thus $6 / 29$ means Jine 29.

family. As in the $\mathrm{F}_{2}$ generation, the mode of the mean dates of her ing of the $\mathrm{F}_{3}$ families corresponds with the mode of the mean dates heading of the Gopher parent.

In connection with analyzing the $\mathrm{F}_{3}$ data it is necessary to know $\mathrm{I}$ only the mean date of heading of each $\mathrm{F}_{3}$ family and of each pl containing the parents, but also something of their relative variabili To obtain such a measure the means and the standard deviations both the means and standard deviations of each parental plot, wi respect to date of heading were calculated. The results are record in Table 8.

One would expect about 95.5 percent of the variates of a norm frequeney distribution to fall within the range delimited by the me: plus or minus two times the standard deviation $(\mathrm{m} \pm 2 \sigma)$. If such 
intermediate between the upper limit marked by the Gopher pare and the lower limit marked by the Black Mesdag parent. The standa: deviations of these $\mathrm{F}_{3}$ families fell within the limits marked by $t$ ] Gopher parent. In column 6 are placed the $40 \mathrm{~F}_{3}$ families whose mea were intermediate between the upper and lower limits indicated by $t$ Gopher and Black Mesdag parents respectively, and whose standa: deviations were greater than those of the plots of Gopher, and in mc cases also greater than those of the plots of Black Mesdag. The thr $\mathrm{F}_{3}$ families placed in column 8 had mean dates of heading similar Black Mesdag but their standard deviations were somewhat greater.

From Table 9 it is apparent that there were six of the 150 families whose dates of heading were similar to that of the Bla Mesdag parent. Both the means and the standard deviations of dat of heading of these six $\mathrm{F}_{3}$ families fall within the limits indicated the Black Mesdag parent. If to these are added the three $\mathrm{F}_{3}$ famili whose mean dates of heading were similar to, but whose variabili was somewhat greater than that of the plots of Black Mesdag, v obtain $9 \mathrm{~F}_{3}$ families breeding like the later parent. On a two fact hypothesis, one would expect about this number of $\mathrm{F}_{3}$ families to bre like the Black Mesdag parent with respect to date of heading. determine more precisely the breeding nature of this character wou require a further study in subsequent generations.

\section{INHERITANCE OF LEAF WIDTH Preliminary Observations}

Before deciding which leaf of the plants to measure for lcaf wid some preliminary studies were made. In 1923 the first, second, ar third leaves (calling the uppermost leaf the first, etc.) of 359 plants Gopher, 354 plants of Black Mesdag, and all of the $F_{2}$ plants we: measured for width. The statistical constants of the various measur ments made on the parents are shown in Table 10 .

There was little absolute difference between the means of the widt] of the first and second leaves of Black Mesdag. In the Gopher parer however, the second leaf was approximately one-third wider than t] first leaf. The third leaves of both parents were somewhat narrow on the average than their respective second leaves. The standar deviations of leaf widths of the Black Mesdag parent were somewh greater than those of the Gopher parent. The variability of leaf widt] of the first leaf in both parents was high, as indicated by the coef cients of variability. The coefficients also show that there was $n$ much difference between the variability of the second and third leav of the two parents. 


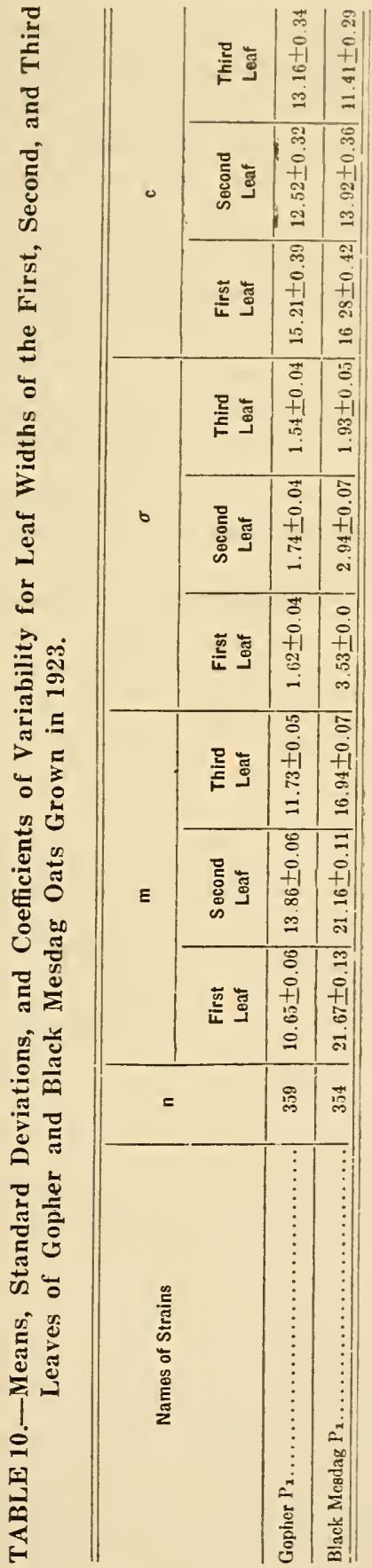


Some interesting relations between leaf widths of the first, seco and third leaves of the parents and of the $F_{2}$ generation are showr Table 11. The highest correlations were found between the widths the second and third leaves, the next highest between the widths the first and second leaves, and the lowest correlations between first and third leaves.

The correlation coefficient between the widths of the first : third leaves of the Gopher parent is $0.24 \pm 0.03$, of the Black Mesc parent $0.65 \pm 0.02$, of the $\mathrm{F}_{2}$ generation of Gopher $\times$ Black Mesc $0.55 \pm 0.03$, and of the $\mathrm{F}_{2}$ generation of Black Mesdag $\times$ Gop $0.48 \pm 0.04$, whereas the coefficients between the widths of second and third leaves are $0.74 \pm 0.02,0.89 \pm 0.01,0.79 \pm 0.01$,

TABLE 11.-The Correlation Between Certain Characters of the Parents. of the $F_{2}$ Generation of Gopher $\times$ Black Mesdag and the Re rocal Grown in 1923.

\begin{tabular}{|c|c|c|c|}
\hline Names of Strains & Nature of Correlation & $n$ & $r$ \\
\hline Gopher $P_{1} \ldots \ldots \ldots \ldots \ldots$ & 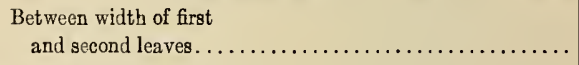 & 359 & 0.62 \\
\hline Black Mesdag $P_{2}$.. & $\begin{array}{l}\text { Between width of first } \\
\text { and second leaves... }\end{array}$ & 354 & $0.85 \pm$ \\
\hline Gopher x Bl. Mes. $F_{z} \ldots \ldots$ & $\begin{array}{l}\text { Between width of first } \\
\text { and second leaves... }\end{array}$ & 323 & $0.70 \pm$ \\
\hline Bl. Mes. $x$ Gopher $F_{2}$.. & $\begin{array}{l}\text { Between width of first } \\
\text { and second leaves... }\end{array}$ & 132 & $0.62 \pm$ \\
\hline Gopher $P_{1} \ldots \ldots$ & $\begin{array}{l}\text { Between width of first } \\
\text { and third leaves..... }\end{array}$ & 359 & $0.24 \pm$. \\
\hline Black Mesdag $\mathrm{P}_{1} \ldots \ldots \ldots \ldots$ & $\begin{array}{l}\text { Between width of first } \\
\text { and third leaves..... }\end{array}$ & 354 & $0.65 \pm$ \\
\hline Gopher x Bl. Mes. $F_{2} \ldots \ldots$. & $\begin{array}{l}\text { Between width of first } \\
\text { and third leaves..... }\end{array}$ & 323 & $0.55 \pm$ \\
\hline Bl. Mes. $x$ Gopher $F_{\mathbf{2}}$.. & $\begin{array}{l}\text { Between width of first } \\
\text { and third leavcs..... }\end{array}$ & 132 & $0.48 \pm$ \\
\hline Gopher $P_{1} \ldots \ldots \ldots \ldots \ldots$ & $\begin{array}{l}\text { Between width of second } \\
\text { and third leaves....... }\end{array}$ & 359 & $0.74 \pm$ \\
\hline Black Mesdag $\mathrm{P}_{1} \ldots$ & $\begin{array}{l}\text { Between width of second } \\
\text { and third leaves....... }\end{array}$ & 354 & $0.89 \pm$ \\
\hline Gopher x BI. Mes. $F_{2} \ldots \ldots$. & $\begin{array}{l}\text { Between width of second } \\
\text { and third leaves....... }\end{array}$ & 323 & $0.79 \pm$ \\
\hline Bl. Mes. $x$ Gopher $F_{2} \ldots \ldots \ldots$ & $\begin{array}{l}\text { Between width of second } \\
\text { and third leaves.................. }\end{array}$ & 132 & $0.78 \pm$ \\
\hline
\end{tabular}


$S \pm 0.02$, respectively. It is of interest to note that with respect to $y$ two leaf widths there is in no ease a significant difference between e coeffieients of the $\mathrm{F}_{2}$ generations of reciprocal erosses.

In view of the fact that the widths of the first leaves' of the plants re more variable than the widths of the second and third leaves, it is decided not to use the first leaf in the inheritance study. The sond leaf rather than the third was finally chosen for this investiga$n$ as the third leaf dried somewhat earlier and therefore was less inable for measurement in the field.

In connection with a study of the inheritance of a size character h as this, the question of number of plants to grow in each $\mathrm{F}_{\text {" family }}$ lally presents itself. In order to obtain some information on this jestion for the particular problem at hand, the $323 \mathrm{~F}_{2}$ plants grown 1923 were studied. The problem was to determine the number of $\mathrm{F}_{2}$ nts necessary to constitute a random sample of the total population. Iis was done by taking at random every fifth individual of the $323 \mathrm{~F}_{2}$ (f widths and throwing them into a frequency distribution, thus five quency distributions, each made up of 65 individuals, were obtained. a similar manner frequency distributions were made up by taking random every tenth, fifteenth, and twentieth individual of the 323 leaf widths.

The means and standard deviations for all four of these frequency tributions were calculated. The distributions of the means and fadard deviations are shown in Tables 12 and 13, respectively. It is lious from these tables that at least 65 individuals should be used in i) to constitute a random sample that would give a trustworthy rex as to the breeding behavior of leaf width in the $F_{2}$ generation. se in the $\mathbf{F}_{2}$ generation maximum variability is obtained, it naturfollows that each $\mathrm{F}_{3}$ family should be represented by the mini$n n$ number of individuals that constitutes a random sample. This

3LE 12.-Frequency Distributions of the Mean Leaf Widths Based on Different Samples Taken From the $F_{2}$ Generation of Gopher $X$ Black Mesdag Grown in 1923.

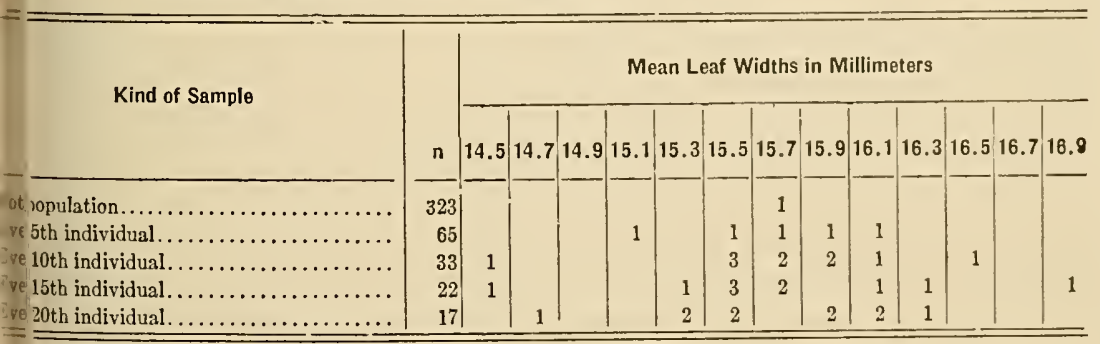


TABLE 13.-Frequency Distributions of the Standard Deviations of L Widths Based on Different Samples Taken From the $F_{2}$ Gene: tion of Gopher $\times$ Black Mesdag Grown in 1923.

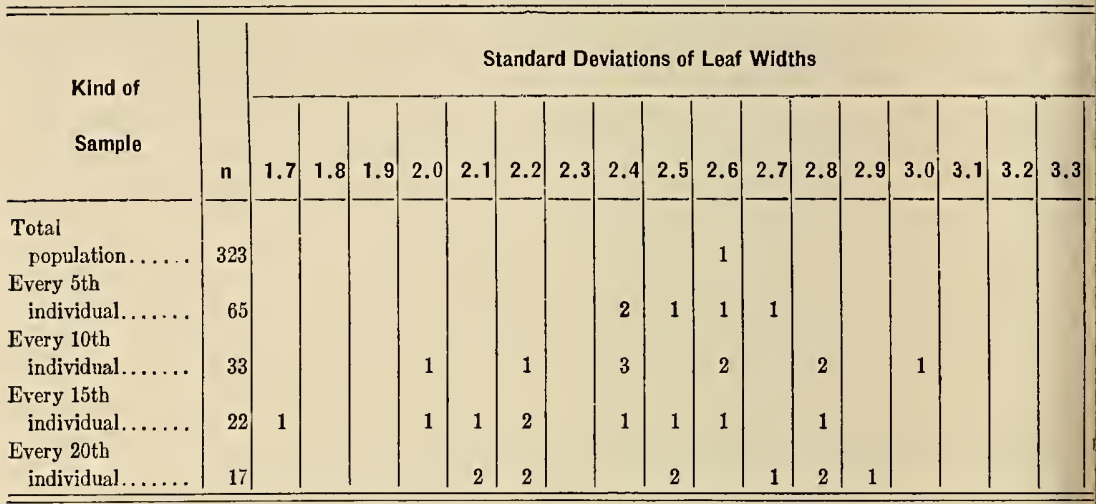

analysis of the $\mathrm{F}_{2}$ generation grown in 1923 indicates that the $\mathrm{F}_{3}$ fan lies grown in 1924 were not large enough. This fact will be shown al in connection with the discussion of the inheritance of leaf width.

\section{Environmental Influence}

As in the case of date of heading, leaf width may be influenced environment and so in 1924 a study was made of the possible effect soil and of number of plants per row on the development of leaf widt The correlation coefficients between the means of leaf widths of conse utive plots of the parents growing with the $F_{3}$ progenies were cor puted as was also the correlation between the means of the leaf widt of the two parents growing in adjacent plots. The influence of numb of plants per plot on mean leaf widths in each of the parents was al studied. The data are presented in Table 14.

TABLE 14.-Correlation Coefficients That Show the Effect of Environment the Development of Leaf Width in the Oat Parents Grown in 19:

\begin{tabular}{|c|c|c|}
\hline Nature of Correlation & n & $\mathbf{r}$ \\
\hline Between mean leaf widths in consecutive plots of Gopher... & 27 & $-0.029 \pm 0$. \\
\hline Between mean leaf widths in consecutive plots of Black Mesdag. ........ & 27 & $+0.262 \pm 0$ \\
\hline Between mean leaf widths of Gopher and of Black Mesdag in adjoining plots... & 31 & $+0.490 \pm 0$ \\
\hline Between mean leaf widths and number of plants per plot of Gopher.......... & 31 & $+0.039 \pm 0$. \\
\hline Between mzan leaf widths and number of plants pcr plot of Black Mesdag. & 31 & $+0.199 \pm 0$ \\
\hline
\end{tabular}

The correlation coefficients show that in no case, except betwee mean leaf widths of Gopher and Black Mesdag grown in adjaces plots, was there a significant correlation. The correlation between $t$ ] mean leaf widths of the adjacent parental plots was $+0.490 \pm 0.0$ : 
hich shows that there was a "place effect" in the development of is character and that the leaf widths of the two parents tended to iry in the same direction. The lack of correlation between the leaf idths of consecutive plots of either parent is probably an indication at the parental plots as ehecks should have been distributed more equently throughout the series. The number of plants per plot iparently did not influence the derelopment of the mean leaf widths either of the parents.

\section{Data in 1923}

The leaf width of individual plants of the $\mathrm{F}_{1}, \mathrm{~F}_{2}$, and $\mathrm{F}_{3}$ generains as well as that of the parents was determined in 1923. This aracter proved to be highly variable and for this reason larger fmilics should have been grown.

The distributions of the leaf widths of the $\mathrm{F}_{1}$ and $\mathrm{F}_{2}$ generations, trether with those of the parents, all grown in close proximity, are swn in Table 15.

The data in Table 15 show that the parents differed considerably ith respect to leaf width. The mean leaf width of the six $F_{1}$ plants $\nabla \mathrm{s}$ intermediate between the parents but it was somewhat nearer to mean leaf width of Black Mesdag than to that of Gopher. The $\mathrm{F}_{2}$ i) tribution had a lower range than the Gopher parent but did not ch the upper range of Black Mesdag. The mean leaf width of the generation was somewhat nearer to the mean leaf width of Gopher $\mathrm{n}$ it was to that of Black Mesdag. The standard deviation of leaf It th of the Black Mesdag parent was almost as great as that of the I generation; the relative variability of the latter, however, was wewhat greater.

The data for the $\mathrm{F}_{3}$ families together with those for the parents th $\mathrm{t}$ were grown with them are shown in Table 16. This table shows distribution of the mean leaf width of each $\mathrm{F}_{3}$ family and, for comison, the distributions of the mean leaf widths of the parental pts. It is obvious from the table that the parental plots differed esiderably with respect to mean leaf width and that the parental tes were recovered in $F_{3}$. There were four $F_{3}$ families with mean widths slightly below the plot of Gopher with the lowest mean width. On the other hand the six $\mathrm{F}_{3}$ families with the highest min leaf widths were eonsiderably below the plots of Black Mesdag wa the higher mean leaf widths. There were only seven of the 139 families within the range of the mean leaf widths of the plots of zk Mesdag. 


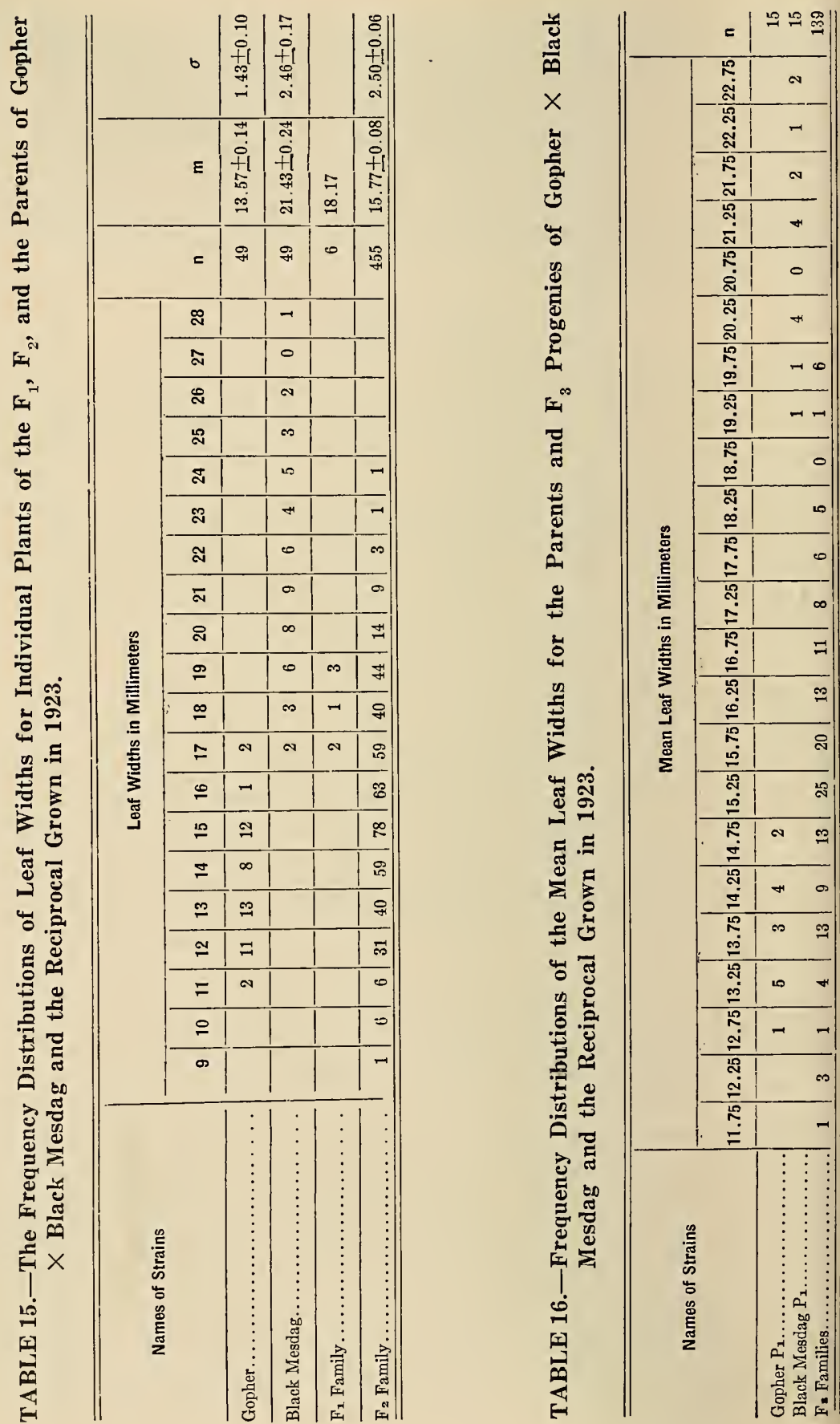


It has been previously mentioned that leaf width was a variable haracter. This was brought out in the 1923 data when an attempt ras made to show the relative variability of the parental plots as comared with the several $\mathrm{F}_{3}$ families. The eoeffieients of variability were alculated for this purpose. The distributions of the eoeffieients for he parental plots and the $\mathrm{F}_{3}$ families are shown in Table 17 . It is rident that the range of variability for the Black Mesdag parent is lmost as great as that for the $\mathrm{F}_{3}$ families. In view of this situation $t$ was not thought worth while to analyze the data further for relative ariability.

\section{Data in 1924}

The leaf widths of individual plants of the parents and the $\mathrm{F}_{2}$ and ${ }_{3}$ generations were determined in 1924 . The frequeney distributions of the $\mathrm{F}_{2}$ generation and the parents which were grown with it are hown in Table 18.

In 1924 the mean leaf width of the $\mathrm{F}_{2}$ generation was intermediate letween the means of the leaf widths of the parents. The variability :f leaf width of the Black Mesdag parent as measured by the standard leviation was almost as great as that of the $\mathrm{F}_{2}$ generation. The distriutions of leaf widths of the two parents as given in Table 18 are kewed to the left, or toward the narrower leaf widths.

If leaf width is an inherited character, a positive correlation hould be obtained between the leaf widths of individual $\mathrm{F}_{2}$ plants and he mean leaf widths of their respective $\mathrm{F}_{3}$ progenies. Such a correation is shown in Table 19. The magnitude of the eorrelation coefficient $+0.512 \pm 0.041$ ) shows that leaf width was definitely transmitted rom the $\mathrm{F}_{2}$ to the $\mathrm{F}_{3}$ progeny.

In Table 20 are recorded the frequency distributions of the mean eaf width of each $\mathrm{F}_{3}$ family and for comparison the mean leaf width if each parental plot.

The mean leaf widths of the two parents do not overlap. as shown y the distribution given in Table 20, although the upper limit of zopher reaches to the lower limit of Black Mesdag. The distribution of the mean leaf widths of the $\mathrm{F}_{3}$ families simulates somewhat a normal requency distribution with a range extending approximately over he combined ranges of the two parents. One $F_{3}$ family, namely 16-6-8, lad a mean leaf width of only $11.82 \pm 0.28$ millimeters with a standard leviation of $2.40 \pm 0.20$ (see Table 33 of appendix). This mean was signifieantly lower than the lowest mean leaf width of any other $\mathrm{F}_{3}$ family or any plot of the Gopher parent. 


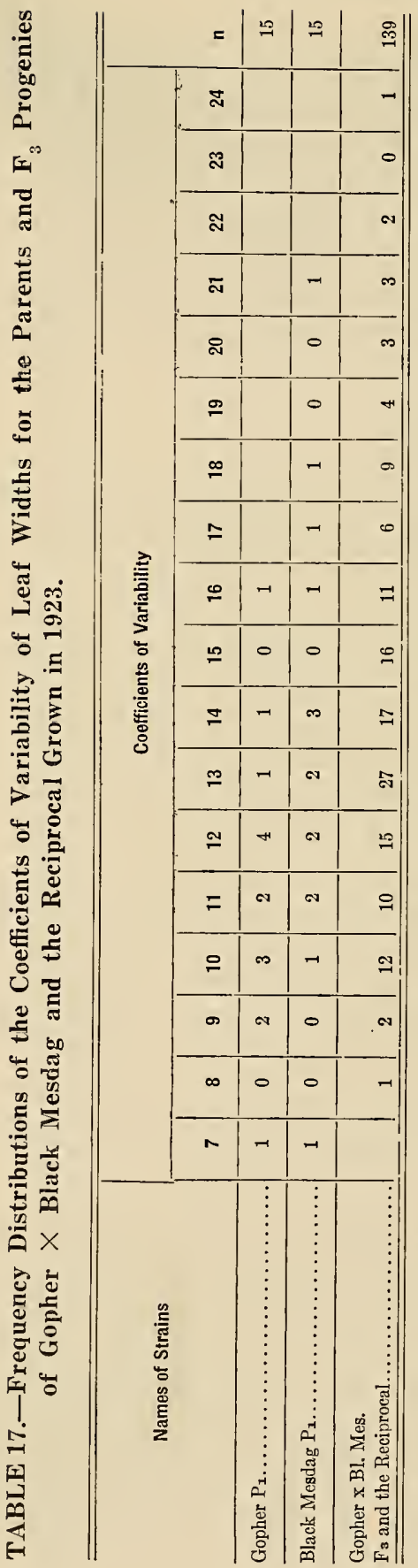

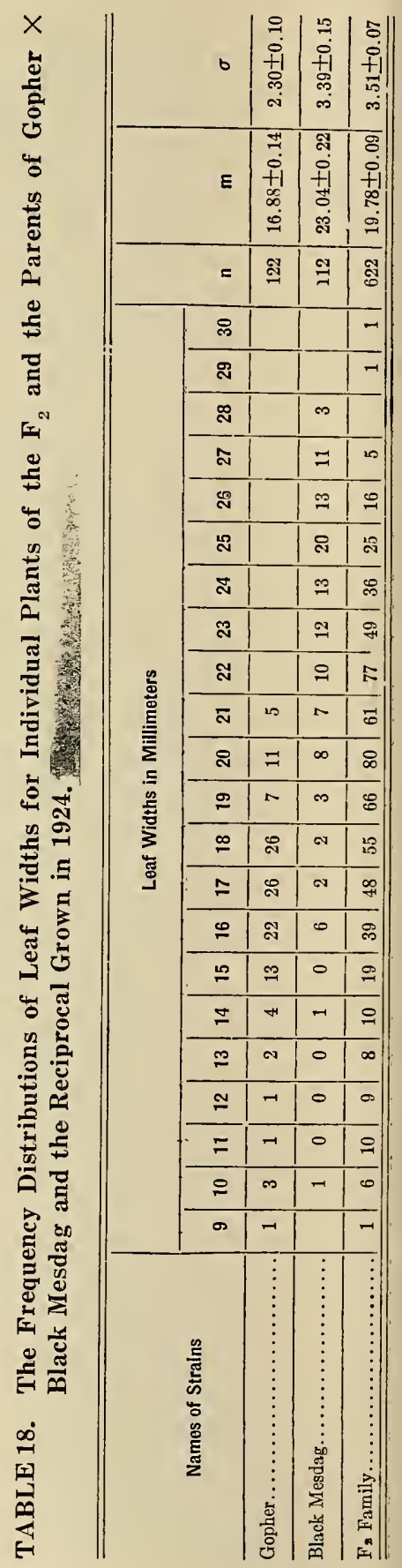


TABLE 19.-Correlation Between Leaf Width of Individual Plants in $\mathrm{F}_{2}$ and the Mean Leaf Width of Their $F_{3}$ Progeny of the Cross Gopher $X$ Black Mesdag and the Reciprocal.

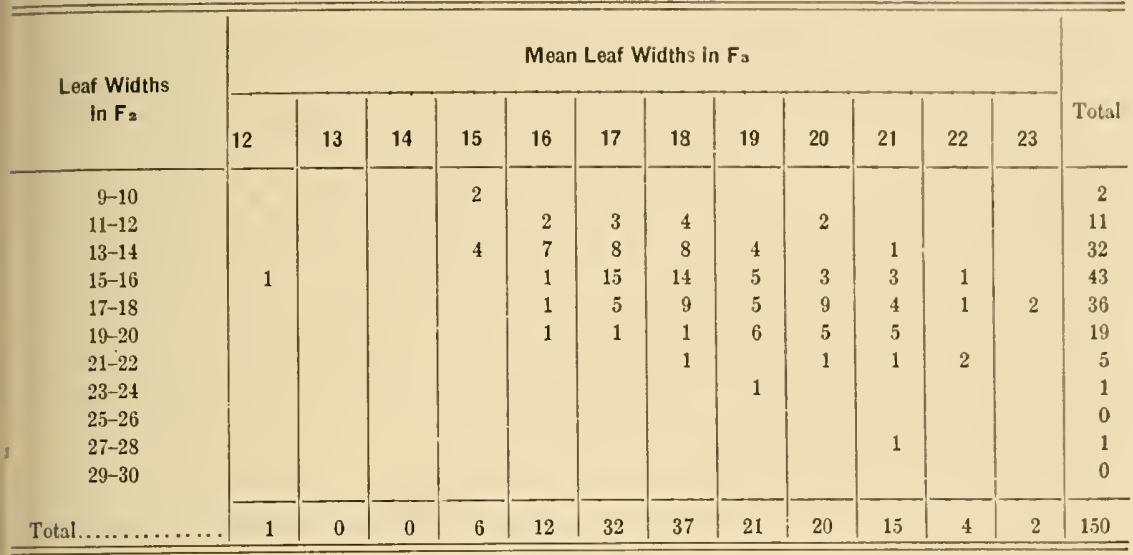

$\mathrm{r}=+0.512 \pm 0.041$

TABLE 20.-Frequency Distributions of the Mean Leaf Widths for the Parents and $F_{3}$ Progenies of Gopher $\times$ Black Mesdag and the Reciprocal Grown in 1924.

Names of Strains

Mean Leaf Widths in Millimeters

In order to determine the variability of the means' and the standard deviations of the parental plots with respect to leaf widths certain calculations were made. For this purpose the mean and standard deviation of the mean leaf widths of each of the two groups of parental plots were determined, and in a similar manner the mean and standard deviation of the standard deviations of each of the two groups of parental plots were computed. The constants obtained are reeorded in Table 21.

In a normal frequency distribution 9.5.5 pereent of the rariates fall within the range delimited by the mean plus or minus two times the standard deviation. Theoretically, then, we would expect about 95.5 pereent of the mean leaf widths of the Gopher plots to fall within the limits of $16.4855 \pm 2 \times 0.7342$ or between 15.0171 and 17.9539 . 
TABLE 21.-The Means and Standard Deviations of Both the Means ad Standard Deviations of Leaf Widths for Each of the Two Grots of Plots Containing the Parents Grown With the $F_{3}$ Progeny $n$ 1924.

\begin{tabular}{|c|c|c|c|c|c|}
\hline Names of Strains & $\begin{array}{c}\text { Number } \\
\text { Plots }\end{array}$ & $\begin{array}{c}\text { M of } \\
\text { Means }\end{array}$ & $\begin{array}{c}\sigma \text { of } \\
\text { Means }\end{array}$ & $\begin{array}{c}\text { M of } \\
\text { S. Devs. }\end{array}$ & $\begin{array}{l}\sigma \text { of } \\
\text { S. Devs }\end{array}$ \\
\hline Gopher........ & 31 & 16.4855 & 0.7342 & $\begin{array}{l}2.0318 \\
2.8939\end{array}$ & 0.398 \\
\hline
\end{tabular}

The limits of these same Gopher plots with respect to standard devi. tions of leaf widths' were between 1.2324 and 2.8312. Likewise t. limits of the Black Mesdag plots were between 19.5702 and $23.6266 \mathrm{f}$ the means of leaf widths, and between 1.9547 and 3.8331 for t] standard deviations of leaf widths.

It is now possible to classify according to the foregoing define limits the mean and standard deviation of leaf widths of each family. This has been done in Table 22 .

TABLE 22.-The Frequency Distributions of Means and Standard Deviatio of Leaf Widths for the $\mathrm{F}_{3}$ Progenies.

\begin{tabular}{|c|c|c|c|c|c|c|c|c|}
\hline $\begin{array}{l}\text { Statistical Constants } \\
\text { and Progeny }\end{array}$ & \multicolumn{7}{|c|}{ Limits } & Total \\
\hline Means.... & $\begin{array}{l}\text { (2) } \\
<\end{array}$ & $\begin{array}{l}(3) \\
\text { Gopher } \\
15.0171 \\
17.9539\end{array}$ & $\begin{array}{l}\text { (4) } \\
<\end{array}$ & $\begin{array}{l}\text { (5) } \\
=\end{array}$ & $\begin{array}{l}\text { (6) } \\
<\end{array}$ & $\begin{array}{c}\text { (7) } \\
\text { Bl. Mes. } \\
19.5702 \\
23.6266\end{array}$ & (8) & (9) \\
\hline s. Deviations.... & $=$ & $\begin{array}{l}1.2324 \\
2.8312\end{array}$ & $=$ & $<$ & $<$ & $\begin{array}{l}1.9547 \\
3.8331\end{array}$ & $<$ & \\
\hline Fa Family $\ldots \ldots \ldots \ldots$ & 1 & 59 & 27 & 11 & 13 & 37 & 2 & 150 \\
\hline
\end{tabular}

In column 2 of Table 22 is placed one $\mathrm{F}_{3}$ family which had a lowe mean leaf width than any Gopher plot and whose standard deviatio: fell within the limits marked by the Gopher parent. This family ha already been discussed. There were $59 \mathrm{~F}_{3}$ families (column 3) whic. bred similar to the Gopher parent with respect to both means anc standard deviations of leaf widths. In column 4 are placed $27 \mathrm{~F}$ families whose standard deviations of leaf widths fell within the limit marked by the Gopher parent but whose mean leaf widths were be tween the upper and lower limits of the Gopher and Black Mesda parents, respectively. Eleven $\mathrm{F}_{3}$ families had mean leaf widths whicl 
41 within the limits indicated by the Gopher parent but their standard Iniations were greater than that of the Gopher parent and in some ises greater than that of the Black Mesdag parent. The $13 \mathrm{~F}_{3}$ famiss with mean leaf widths between the upper limit of the Gopher frent and the lower limit of the other parent are recorded in lumn 6. 'The standard deviations of leaf width of these families were - itside the limits of the Gopher parent and in some eases also outside ie limits of the Blaek Mesdag parents. There were $37 \mathrm{~F}_{3}$ families hieh bred in a manner similar to that of the Black Mesdag parent ith respect to means and standard deviations of leaf width. Two of te $150 \mathrm{~F}_{3}$ families had mean leaf widths which fell within the limits dicated by Black Mesdag but they had standard deviations that fell hitsicle the limits marked by this parent.

Considering all the data on leaf width, it is apparent that this maracter is a rariable one and for purposes of making a more exact 1alysis of its inheritance larger $\mathrm{F}_{3}$ families should have been grown. or such a study it would be highly desirable to earry the analysis rough the $\mathrm{F}_{4}$ and subsequent generations. The data presented, hower, do seem to justify the conclusion that leaf width is a definitely "herited character and that the manner of its inheritance is dependent on more than one factor difference.

\section{INHERITANCE OF NUIMBER OF CULMS}

The inheritance of number of culms was studied in 1923 only, as 1924 the differenee between the two parents with respect to this araeter was not clearly defined, owing largely to seasonal influence.

1923 the mean number of culms of 443 Gopher plants was $12 \pm 0.11$ and of 381 Black Mesdag plants was $4.45 \pm 0.08$. In 1924 e mean number of culms of 328 Gopher plants was $3.16 \pm 0.04$ and 301 Black Mesdag plants $2.36 \pm 0.03$.

The frequeney distributions of number of eulms of the $F_{3}$ plants al the parents which were grown with them in 1923 are shown in ible 23.

It may be noted that there are 68 and 62 plants of Gopher and ack Mesdag, respectively, reported as growing with the $\mathrm{F}_{2}$ generain in 1923, whereas in Table 15, in eonnection with the leaf width idy, there were but 49 plants of each parent reported. The reason $r$ the smaller number of plants in the latter case is that in 1923 only ose parental plants were measured for leaf width which had three per leaves whose width could be determined. If the lower leaf had thered the plant was eliminated. 

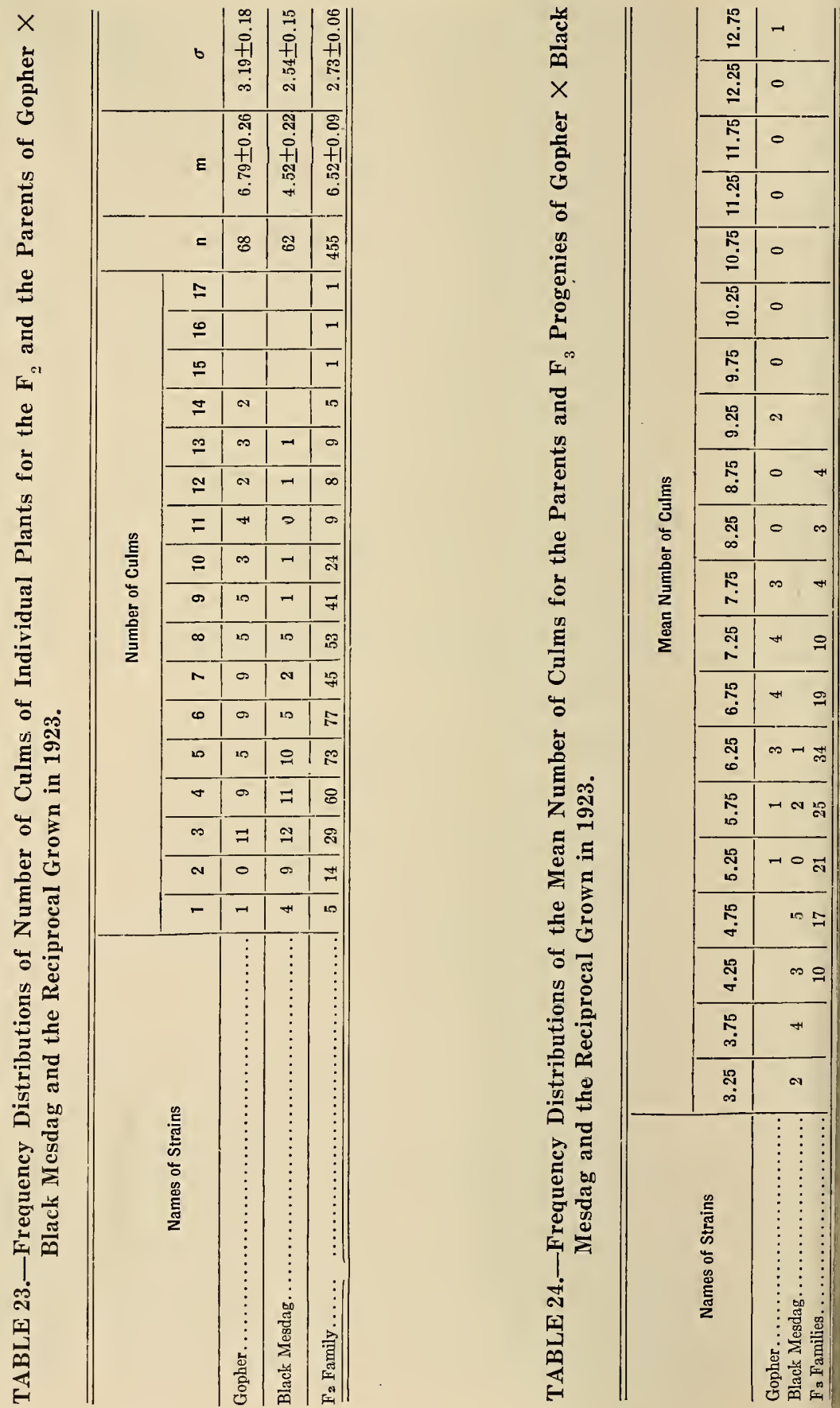
It may be seen from Table 23 that the modes of the distributions r number of enlms in the two parents correspond, although there re relatively few plants of Black Mesclag with a large number of Ims. The means of the number of culms of Gopher and Black Mesdag re $6.79 \pm 0.26$ and $4.52 \pm 0.22$, respectively, whereas, the mean num$\mathrm{r}$ of culms of the $\mathrm{F}_{2}$ generation was $6.52 \pm 0.09$. The belavior the $\mathrm{F}_{2}$ generation seems to indicate that a high number of culms was ierited as a dominant character. It is apparent, too, that the num$r$ of eulms was a variable character and one that was probably luenced considerably by environment.

That the number of culms is an inlerited character, is more elearly own by the data obtained from the $F_{3}$ families. In Table 24 the rquency distributions of the mean number of eulms of the $\mathrm{F}_{3}$ families d the parents which were grown with them are shown. It is obrious it some of the $\mathrm{F}_{3}$ families bred like the Gopher parent with respect mean number of enlms and other $\mathrm{F}_{3}$ families like the Blaek Nesclag rent.

\section{INHERITANCE OF COLOR OF SEED}

The Gopher parent of the oat crosses diseussed in this bulletin had ite seed and the Black Mesdag had black seed. The seeds of the $F_{1}$ ints were black but not quite of the same intensity as the seed of black parent. Of the $455 \mathrm{~F}_{2}$ plants grown in 1923 , 355 had black d $d$ and 100 had white seed. The deviation from expectation on a nohybrid basis was $13.7 \pm 6.2$. In 1924 there were $622 \mathrm{~F}_{2}$ indiuals, of which 483 were black-seeded and 139 were white-secded nts. In this case the deviation from monohybrid expeetation was $5 \pm 7.3$.

Additional evidence eoncerning the inheritance of seed color in s oat cross may be obtained from the $F_{3}$ generation grown in 1924. all there were $150 \mathrm{~F}_{3}$ families grown during this year. Of this inber 40 bred true for black seed, 79 segregated for seed color, and bred true for white seed. This result is in fairly close $(\mathrm{P}=0.4856)$ eement with expectation, on the assumption that the parents difed in regard to seed eolor by a single factor.

\section{INTERRELATION OF HERITABLE CHARACTERS}

The relation of one character to another is of importance. If two racters are closely linked in their inheritance, and it is desirable break this linkage, it is neessary to grow a greater number of pring than is the case if the two characters are independent in 
their inheritance. A study of the relation in inheritance of the fo characters herein considered was made.

\section{Seed Color and Other Characters}

In Table 25 are presented the data based on the $\mathrm{F}_{2}$ generati grown in 1923 which bring out the relationships between color of se and the other three characters. The reciprocals, although no differen was observed between them, have been kept separate in this table.

The difference between the mean dates of heading for the blac seeded and the white-seeded $F_{2}$ plants of Gopher $\times$ Black Mesdag w $2.34 \pm 0.35$, and of Black Mesdag $\times$ Gopher, 1.21 \pm 0.57 , both i stances being in favor of white-seeded plants. The former difference significant in the light of its probable error, but the latter is' not. Sin the black-seeded parent was also the later parent, the significant $d$ ference obtained was certainly not due to close genetic linkage.

With respect to mean number of culms the black-seeded and whi seeded $\mathrm{F}_{2}$ plants did not differ significantly from one another in eith the Gopher $\times$ Black Mesdag or the reciprocal crosst.

The $\mathrm{F}_{2}$ plants with black seed of Gopher $\times$ Black Mesdag had mean leaf width of $15.39 \pm 0.11$, whereas the plants with white se had a mean leaf width of $16.69 \pm 0.20$. The difference of $1.30 \pm 0$. between these means is more than five times its probable error. $\mathrm{T}$ difference between the means of leaf width of the black-seeded at white-seeded $\mathrm{F}_{2}$ plants of Black Mesdag $\times$ Gopher is not significar Black seeds and wicle leaves were associated in one of the parents this cross so it is apparent that there is no evidence of linkage here.

The data obtained from the $\mathrm{F}_{2}$ generations grown in 1924 are 1 corded in Table 26. Here again there is no evidence of a genetic lin age between the several character pairs as they entered the cros's. the Black Mesdag parent, black seed was associated with late maturi a small number of culms, and wide leaves, as contrasted with $t$ Gopher parent in which white seed was associated with early maturi a large number of culms, and narrow leaves. In view of the eviden presented, it may be concluded that color of seed is not linked inheritance with any of the other characters studied in this investig tion.

\section{Leaf Width and Number of Culms}

The relation in inheritance of leaf width to number of culms w studied by determining the degree of correlation between these che acters in the $\mathrm{F}_{2}$ generation as compared with the parents. Unfort nately, the relation between these two characters was not determin 


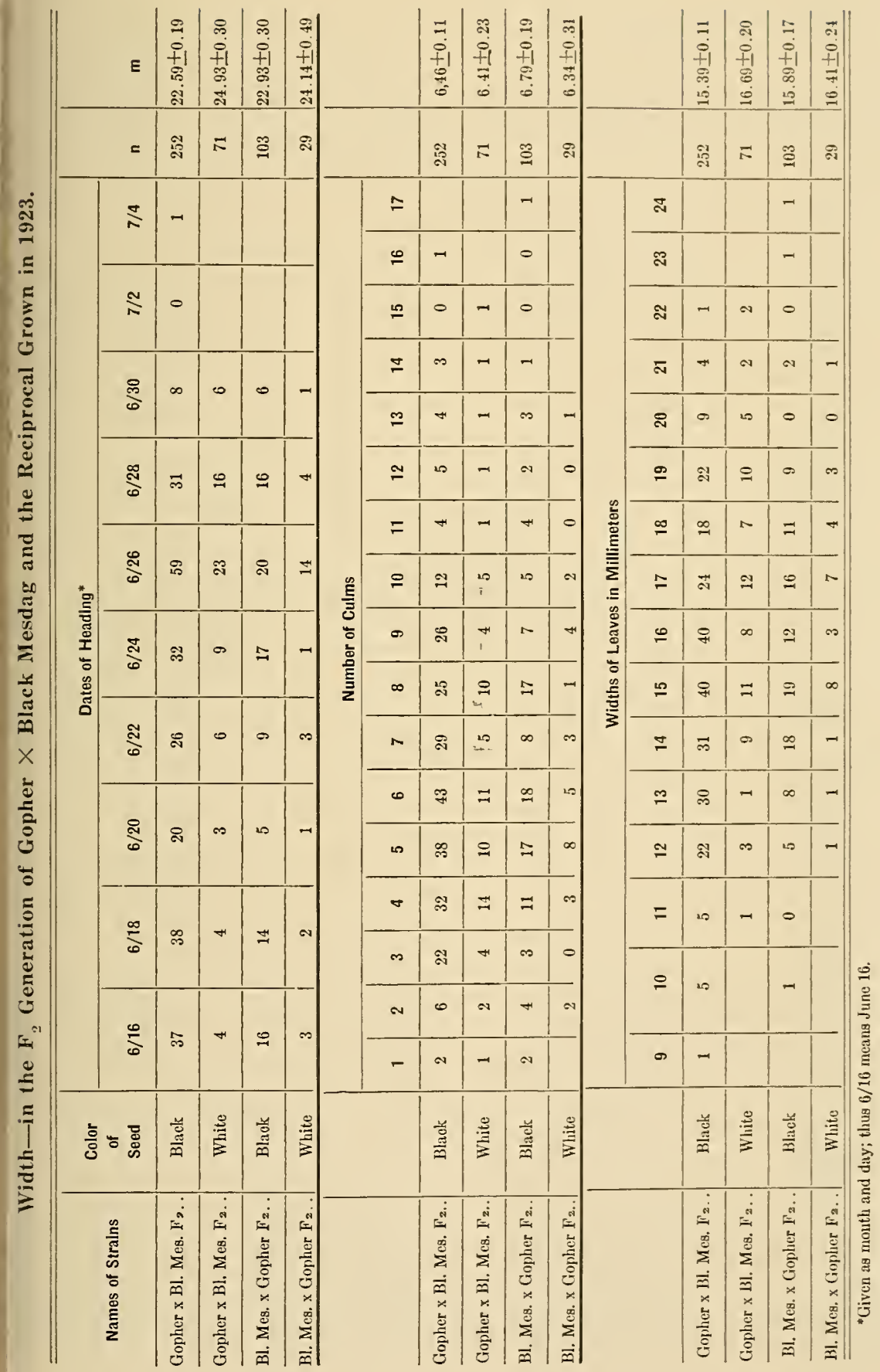




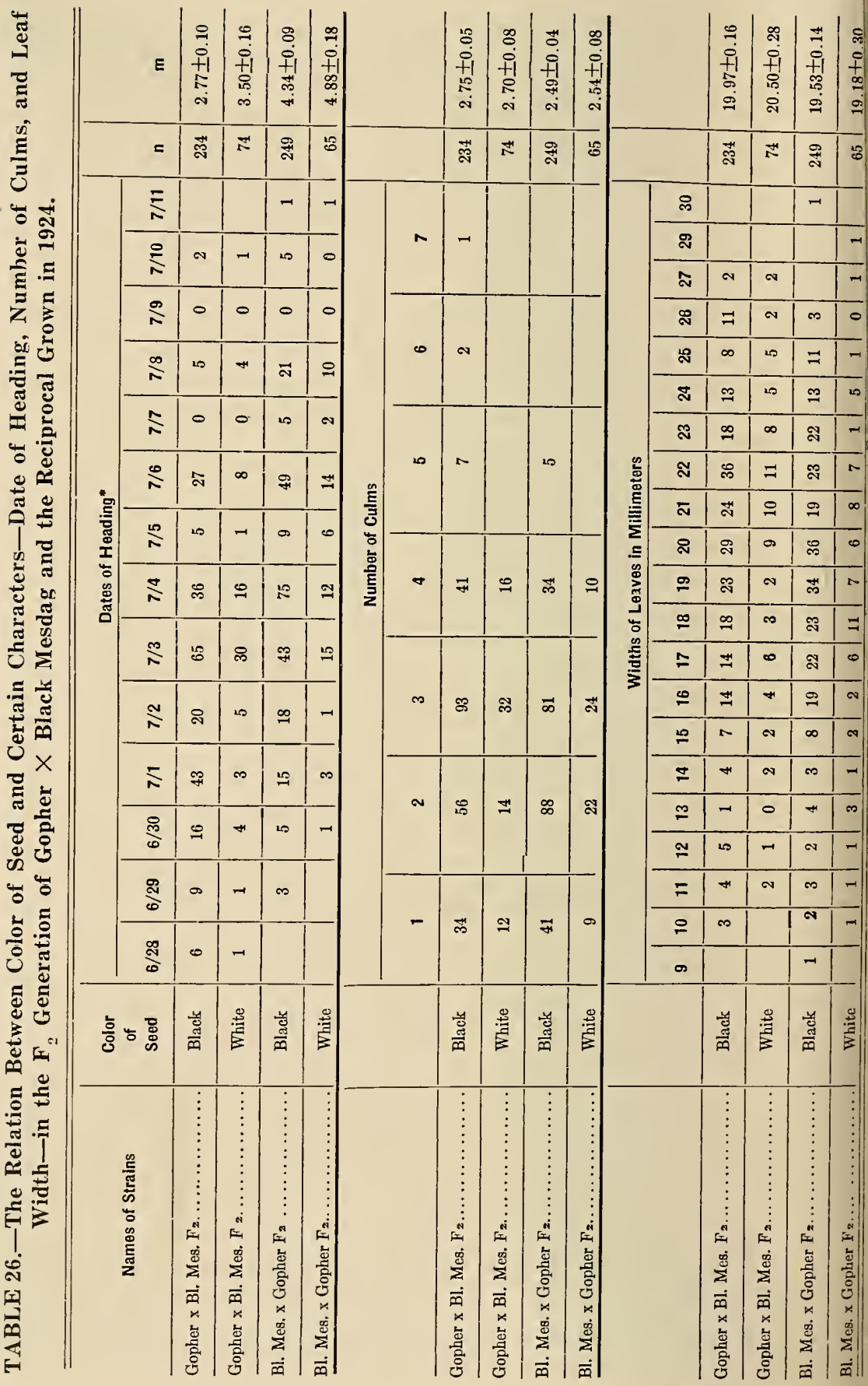


or the parents in 1923 , but it was determined for them in 1924. The sults are tabulated in 'Table 27.

ABLE 27.-The Correlation Between Leaf Width and Number of Culms in the $F_{2}$ Generation of Gopher $\times$ Black Mesdag and the Reciprocal as Compared with the Parents.

\begin{tabular}{|c|c|c|c|}
\hline Names of Stralns & $\begin{array}{l}\text { Year } \\
\text { Grown }\end{array}$ & n & r \\
\hline 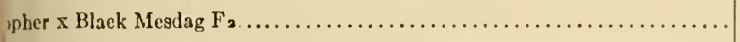 & 1923 & 323 & $+0.30 \pm 0.03$ \\
\hline 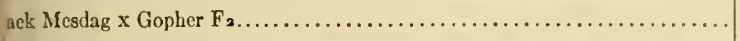 & 1923 & 132 & $+0.24 \pm 0.06$ \\
\hline 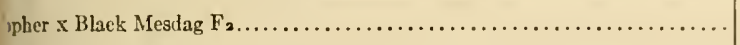 & 1924 & 308 & $+0.41 \pm 0.03$ \\
\hline 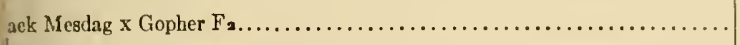 & 1924 & 314 & $+0.41 \pm 0.03$ \\
\hline 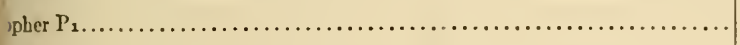 & 1924 & 328 & $+0.53 \pm 0.03$ \\
\hline sek Mesdag Px......... & 1924 & 301 & $+0.47 \pm 0.03$ \\
\hline
\end{tabular}

From the last column of Table 27, it is obvious that there is a ositive correlation between leaf width and number of eulms both in 1e $\mathbf{F}_{2}$ generations and the parents. Considering only the plants that ere grown in 1924, we find that the magnitude of the eoeffieients of orrelation between leaf width and number of culms in the reciprocal 2 generations is identical and that the magnitude of the coefficients or these same charaeters in the parents is somewhat greater although ot significantly so. In 1923 the correlation between leaf width and umber of culms was not as marked as in 1924. The foregoing correlaons are somatic and not genetic since broad leaves and few culms, nd narrow leaves and many culms were associated in the parents.

\section{Leaf Width and Date of Heading}

The relation in inheritance between leaf width and date of heading as also studied by means of correlation. In the parents broad leaves ere assoeiated with late maturity and narrow leaves with early laturity. In Table 28 are recorded the correlation eoefficients obined for these characters in the parents of the $\mathrm{F}_{2}$ generations.

In 1923 the correlation between leaf width and date of heading as sensibly zero in both $\mathrm{F}_{2}$ erosses, whereas in 1924 there was a slight egative correlation between these two characters in the $F_{2}$ generaons. The parents which were studied in 1924 only, showed a somehat higher negative correlation between leaf width and date of eading than did the $\mathrm{F}_{2}$ generations grown the same rear. These data stainly show there was no elose linkage between leaf width and date 
TABLE 28.-The Correlation Between Leaf Width and Date of Heading in $F_{2}$ Generation of Gopher $\times$ Black Mesdag and the Reciprocal Compared With the Parents.

\begin{tabular}{|c|c|c|c|}
\hline Names of Strains & $\begin{array}{l}\text { Year } \\
\text { Grown }\end{array}$ & $\mathbf{n}$ & $\mathbf{r}$ \\
\hline 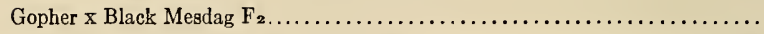 & 1923 & 323 & $+0.08 \pm$ \\
\hline 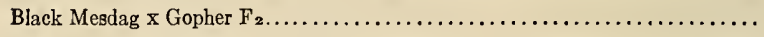 & 1923 & 132 & $+0.07 \pm$ \\
\hline 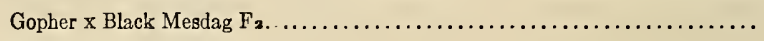 & 1924 & 308 & $-0.15 \pm$ \\
\hline 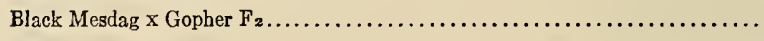 & 1924 & 314 & 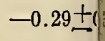 \\
\hline 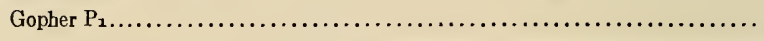 & 1924 & 328 & $-0.44 \pm$ \\
\hline Black Mesdag $\mathrm{P}_{1} \ldots \ldots \ldots \ldots$ & 1924 & 301 & $-0.50 \pm t$ \\
\hline
\end{tabular}

of heading in this oat cross. Environment seems to have influenc the correlation of these characters to some extent as is indicated 1 the difference obtained between the coefficients for the $\mathrm{F}_{2}$ generatio in 1923 and in 1924.

\section{Date of Heading and Number of Culms}

The Gopher parent was earlier in heading and had a relative larger number of culms than the Black Mesdag parent. If these tv characters are linked in inheritance one would expect a negati correlation between date of heading and number of culms in the $]$ generation. Such a negative relation was found as is shown in Tab 29. Before drawing conclusions based entirely on the $\mathrm{F}_{2}$ generatio however, it is necessary to know something of the relation betwee TABLE 29.-The Correlation Between Date of Heading and Number of Culn in the $F_{2}$ Generation of Gopher $\times$ Black Mesdag and the Reci rocal as Compared With the Parents.

\begin{tabular}{|c|c|c|c|}
\hline Names of Strains & $\begin{array}{l}\text { Year } \\
\text { Grown }\end{array}$ & $\mathrm{n}$ & $r$ \\
\hline Gopher x Black Mesdag $F_{2} \ldots \ldots \ldots \ldots \ldots \ldots \ldots \ldots$ & 1923 & 323 & $-0.38 \pm 0$ \\
\hline Black Mesdag x Gopher $\mathrm{F}_{2} \ldots \ldots \ldots \ldots$. & 1923 & 132 & $-0.32 \pm 0$ \\
\hline Gopher x Black Mesdag F $\ldots \ldots \ldots \ldots \ldots \ldots \ldots \ldots$ & 1924 & 308 & $-0.20 \pm 0.1$ \\
\hline 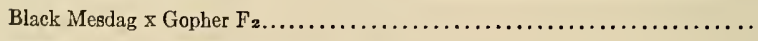 & 1924 & 314 & $-0.36 \pm 0.1$ \\
\hline Gopher $P_{2} \ldots \ldots \ldots . .$. & 1924 & 328 & $-0.54 \pm 0.1$ \\
\hline Black Mesdag $\mathrm{P}_{1} \ldots \ldots \ldots \ldots \ldots \ldots \ldots \ldots$ & 1924 & 301 & $-0.38 \pm 0$. \\
\hline
\end{tabular}


1ese two characters in each parent. Such a study was made in 1924 ut not in 1923.

It is obvious from the last column of Table 29 that a negative corslation between date of heading and number of culms was found in 1e $\mathbf{F}_{2}$ generations grown in both 1923 and 1924, but it is also evident lat the negative correlation between these same characters in the arents was just as marked (in one case more so) as the negative correitions in the $\mathrm{F}_{2}$ generations grown the same year. Apparently, there no linkage between date of heading and number of culms.

\section{SUIMIMARY AND CONCLUSIONS}

1.-The $\mathrm{F}_{2}, \mathrm{~F}_{3}$, and in some cases the $\mathrm{F}_{1}$ generations of certain oat rosses Gopher $\times$ Black Mesdag and the reciprocal were studied durig two years to determine the inheritance of date of heading, leaf idth, number of culms, and color of seed. In all, there were grown $119236 \mathrm{~F}_{1}$ plants, $455 \mathrm{~F}_{2}$ plants, and $139 \mathrm{~F}_{3}$ families, and in 1924 lere were grown $622 \mathrm{~F}_{2}$ plants and $150 \mathrm{~F}_{3}$ families. The parents were rown at regular intervals among the progeny in both years of the speriment.

2.-Earliness was found to be inherited as a dominant character nd some evidence was obtained which indicated that in this particu$r$ cross there were at least two factor differences concerned.

3.-Leaf width determined at the widest part of the leaf proved ) be a variable character and one that was influenced to a marked egree by environment. On the basis of a preliminary study the secnd leaf, numbering from the top down, was found to be most satisactory for measuring. Data are presented to show that leaf width is $n$ inherited character, but the manner of its inheritance was not etermined. The distribution obtained in the $\mathrm{F}_{2}$ generation and the ehavior of the $F_{3}$ families with respect to leaf width was rather pical of what occurs when a cross is made involving a quantitative haracter dependent on multiple factors for its expression. One $\mathbf{F}_{\mathbf{3}}$ mily grown in 1924 had a mean leaf width significantly less than the lean leaf width of any plot of Gopher, the narrow-leaved parent.

4.-Number of eulms, like leaf width, is a character which is reatly influenced by environment. In 1923 the difference between re mean number of culms of Gopher and Black Mesdag was much rown in 1923 show that number of culms is an inherited character. reater than the difference in 1924. Data on the $\mathrm{F}_{2}$ and $\mathrm{F}_{3}$ generations 
5.-Black seed color in the cross reported here was found to dominant to white seed color, and was found to be dependent upon single factor difference for its' inheritance.

6.-No positive evidence of close linkage was found between ar two of the four characters studied, namely, date of heading, leaf widt number of culms, and color of seed. 


\section{APPENDIX}

The planting plan showing the arrangement of the plots on which e $\mathrm{F}_{3}$ families and the parents were grown in 1924 is indicated in 'ble 30 , and also in Table 31 . The end of each series is marked by heavy line. The plots were numbered consecutively and in one direcin only; thus the first plot of the first series was just opposite, and iross the alley from, the first plot of the second series. In Table 30 te frequency distributions of date of heading of the $\mathrm{F}_{3}$ families and te parents grown with them are shown, and the frequency distribuins of leaf width for the same plants are given in Table 31 . 
TABLE 30.-Frequency Distributions of Date of Heading of the $F_{3}$ Fam and the Parents of Gopher $\times$ Black Mesdag and the Recipr Grown in 1924. The Planting Plan is Indicated by the Arrase ment of the Strains.

\begin{tabular}{|c|c|c|c|c|c|c|c|c|c|c|c|c|c|c|c|c|c|c|}
\hline \multirow[b]{2}{*}{ Names of Stralns } & \multicolumn{18}{|c|}{ Dates of Heading ( $1=$ June 26$)$} \\
\hline & 1 & 2 & 3 & 4 & 5 & 6 & 7 & 8 & 9 & 10 & 11 & 12 & 13 & $|14|$ & 15 & 16 & $|17|$ & $\mid 18$ \\
\hline $\begin{array}{l}\text { B1. Mes. } \mathrm{P}_{1} \ldots \ldots \ldots \\
\text { Gopher } \mathrm{P}_{1} \ldots \ldots \ldots \ldots \\
17-6-26 \mathrm{~F}_{\mathrm{z}} \ldots \ldots \ldots \\
17-6-2 \mathrm{~F} . \ldots \ldots \ldots \\
17-6-3 \mathrm{~F}_{\mathrm{s}} \ldots \ldots \ldots \ldots \\
17-6-4 \mathrm{~F}_{\mathrm{s}} \ldots \ldots \ldots \ldots \\
17-6-5 \mathrm{~F}_{\mathrm{s}} \ldots \ldots \ldots \ldots\end{array}$ & & & 1 & 1 & $\begin{array}{l}8 \\
6\end{array}$ & $\begin{array}{r}11 \\
3 \\
2\end{array}$ & $\begin{array}{l}6 \\
4 \\
1\end{array}$ & $\begin{array}{r}15 \\
17 \\
8 \\
4 \\
2\end{array}$ & $\begin{array}{r}2 \\
4 \\
13 \\
4 \\
2 \\
1\end{array}$ & $\begin{array}{r}1 \\
2 \\
9 \\
11 \\
0\end{array}$ & $\begin{array}{r}3 \\
4 \\
21 \\
14 \\
1\end{array}$ & \begin{tabular}{l|}
2 \\
\\
2 \\
1 \\
1 \\
5
\end{tabular} & $\begin{array}{r}8 \\
\\
7 \\
10 \\
6\end{array}$ & $\begin{array}{l}9 \\
1 \\
4\end{array}$ & 15 & 0 & 6 & 1 \\
\hline 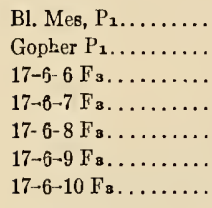 & & & 1 & 0 & $\begin{array}{l}6 \\
2 \\
1 \\
4\end{array}$ & $\begin{array}{r}18 \\
4 \\
3 \\
6 \\
2\end{array}$ & $\begin{array}{r}5 \\
4 \\
0 \\
11 \\
2\end{array}$ & $\begin{array}{r}12 \\
2 \\
13 \\
5 \\
20 \\
12\end{array}$ & $\begin{array}{r}1 \\
11 \\
8 \\
1 \\
12\end{array}$ & $\begin{array}{l}1 \\
3 \\
2 \\
4 \\
7\end{array}$ & $\begin{array}{r}8 \\
5 \\
12 \\
\\
10\end{array}$ & $\begin{array}{r}5 \\
10 \\
1 \\
4 \\
1\end{array}$ & \begin{tabular}{|c|}
3 \\
18 \\
6
\end{tabular} & $\begin{array}{l}4 \\
2\end{array}$ & 17 & 1 & 10 & 1 \\
\hline $\begin{array}{l}\text { B1. Mes. } \mathrm{P}_{1} \ldots \ldots \ldots \\
\text { Gopher, } \mathrm{P}_{1} \ldots \ldots \ldots \\
17-6-11 \mathrm{~F}_{\mathrm{s}} \ldots \ldots \ldots \\
17-6-12 \mathrm{~F}_{\mathrm{s}} \ldots \ldots \ldots \\
17-6-13 \mathrm{~F}_{\mathrm{s}} \ldots \ldots \ldots \\
17-6-14 \mathrm{~F}_{\mathrm{s}} \ldots \ldots \ldots \\
17-6-15 \mathrm{~F}_{\mathrm{s}} \ldots \ldots \ldots\end{array}$ & & & 1 & 4 & $\begin{array}{l}7 \\
1 \\
2 \\
2 \\
5\end{array}$ & $\begin{array}{r}11 \\
1 \\
4 \\
1 \\
5 \\
12\end{array}$ & $\begin{array}{l}5 \\
2 \\
0 \\
7 \\
2\end{array}$ & $\begin{array}{r}15 \\
7 \\
6 \\
19 \\
9\end{array}$ & $\begin{array}{r}5 \\
4 \\
17 \\
20 \\
6 \\
1\end{array}$ & $\begin{array}{l}2 \\
1 \\
3 \\
4 \\
2\end{array}$ & $\begin{array}{r}8 \\
11 \\
5 \\
2\end{array}$ & $\begin{array}{l}1 \\
6 \\
2\end{array}$ & $\begin{array}{r}11 \\
5\end{array}$ & 2 & 21 & 1 & $\begin{array}{l}6 \\
1\end{array}$ & \\
\hline $\begin{array}{l}\text { Bl. Mes. } \mathrm{P}_{1} \ldots \ldots \ldots \\
\text { Gopher } \mathrm{P}_{1} \ldots \ldots \ldots \ldots \\
17-6-16 \mathrm{~F}_{\mathrm{s}} \ldots \ldots \ldots \\
17-6-17 \mathrm{~F}_{\mathrm{s}} \ldots \ldots \ldots \\
17-6-18 \mathrm{~F}_{\mathrm{s}} \ldots \ldots \ldots \\
17-6-19 \mathrm{~F}_{\mathrm{s}} \ldots \ldots \ldots \\
17-6-30 \mathrm{~F}_{\mathrm{s}} \ldots \ldots \ldots \ldots\end{array}$ & 2 & 2 & $\begin{array}{l}1 \\
3 \\
5\end{array}$ & $\begin{array}{l}3 \\
3 \\
6 \\
1 \\
9\end{array}$ & \begin{tabular}{r|}
9 \\
1 \\
9 \\
2 \\
10
\end{tabular} & $\begin{array}{r}19 \\
6 \\
10 \\
9 \\
8\end{array}$ & $\begin{array}{l}4 \\
1 \\
3 \\
4 \\
2\end{array}$ & $\begin{array}{r}8 \\
15 \\
9 \\
13 \\
2\end{array}$ & $\begin{array}{r}9 \\
14 \\
4\end{array}$ & $\begin{array}{c}4 \\
2 \\
13\end{array}$ & 16 & 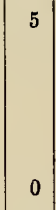 & 3 & 0 & 23 & 0 & 3 & \\
\hline 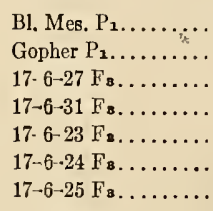 & & 1 & 0 & $\begin{array}{l}1 \\
1\end{array}$ & $\begin{array}{l}2 \\
4 \\
4 \\
3\end{array}$ & $\begin{array}{r}7 \\
1 \\
7 \\
15 \\
9\end{array}$ & $\begin{array}{l}6 \\
\\
3 \\
3 \\
4\end{array}$ & $\begin{array}{r}25 \\
1 \\
26 \\
19 \\
20\end{array}$ & $\begin{array}{l}1 \\
9 \\
6 \\
3 \\
3 \\
2\end{array}$ & $\begin{array}{l}5 \\
6 \\
1 \\
0\end{array}$ & $\begin{array}{r}15 \\
6 \\
2\end{array}$ & $\begin{array}{l}5 \\
1 \\
6\end{array}$ & $\begin{array}{l}15 \\
10 \\
14\end{array}$ & $\begin{array}{l}11 \\
1\end{array}$ & $\begin{array}{r}14 \\
1 \\
6\end{array}$ & & 6 & \\
\hline $\begin{array}{l}\text { Bl. Mes. } P_{1} \ldots \ldots \ldots \\
\text { Gopher } P_{1} \ldots \ldots \ldots \ldots \\
17-7-26 F_{8} \ldots \ldots \ldots\end{array}$ & & & 1 & $\begin{array}{l}1 \\
2\end{array}$ & $\begin{array}{l}5 \\
5\end{array}$ & $\begin{array}{l}8 \\
6\end{array}$ & $\begin{array}{l}2 \\
5\end{array}$ & $\begin{array}{l}10 \\
19\end{array}$ & $\begin{array}{l}4 \\
3\end{array}$ & $\begin{array}{l}5 \\
2\end{array}$ & 1 & 5 & 7 & 4 & 11 & 1 & 2 & \\
\hline $\begin{array}{l}17-7-2 \mathrm{~F}_{\mathrm{s}} \ldots \ldots \ldots \\
17-7-3 \mathrm{~F}_{\mathrm{s}} \ldots \ldots \ldots \ldots \\
17-7-4 \mathrm{~F}_{\mathrm{s}} \ldots \ldots \ldots \\
17-7-5 \mathrm{~F}_{\mathbf{2}} \ldots \ldots \ldots \ldots\end{array}$ & & & & 1 & $\begin{array}{l}2 \\
2\end{array}$ & $\begin{array}{l}5 \\
2 \\
2\end{array}$ & $\begin{array}{l}1 \\
1 \\
1\end{array}$ & \begin{tabular}{l|}
5 \\
8 \\
2 \\
3
\end{tabular} & $\begin{array}{r}15 \\
15 \\
3 \\
12 \\
\end{array}$ & $\begin{array}{l}4 \\
0 \\
5 \\
4\end{array}$ & $\begin{array}{r}5 \\
12 \\
9 \\
12\end{array}$ & $\begin{array}{l}2 \\
3 \\
0\end{array}$ & $\left|\begin{array}{r}16 \\
5\end{array}\right|$ & $\left|\begin{array}{r}21 \\
0\end{array}\right|$ & $\begin{array}{l}2 \\
2\end{array}$ & $\begin{array}{l}1 \\
0\end{array}$ & $\begin{array}{l}2 \\
0\end{array}$ & 1 \\
\hline
\end{tabular}

(Continued) 


\section{BLE 30.-Continued.}

\begin{tabular}{|c|c|c|c|c|c|c|c|c|c|c|c|c|c|c|c|c|c|c|c|}
\hline \multirow[b]{2}{*}{ mes of Strains } & \multicolumn{18}{|c|}{ Dates of Headlng ( $1=$ June 26 ) } & \multirow[b]{2}{*}{$n$} \\
\hline & 1 & 2 & 3 & 4 & 5 & 6 & 7 & 8 & 9 & 10 & 11 & 12 & 13 & 14 & 15 & 16 & 17 & 18 & \\
\hline 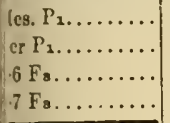 & & & & 12 & 12 & $\begin{array}{l}14 \\
19\end{array}$ & $\begin{array}{l}1 \\
1 \\
0\end{array}$ & $\begin{array}{r}23 \\
7 \\
4\end{array}$ & $\begin{array}{r}2 \\
18\end{array}$ & 3 & 7 & & $\begin{array}{r}13 \\
3\end{array}$ & 0 & 14 & 1 & 4 & 4 & $\begin{array}{l}36 \\
40 \\
39 \\
47\end{array}$ \\
\hline $\begin{array}{c}8 \mathrm{~F} \mathbf{s} \ldots \ldots \ldots \\
9 \mathrm{~F} . \ldots \ldots \ldots \\
10 \mathrm{~F} . \ldots \ldots \ldots\end{array}$ & & & & & & 3 & 1 & $\begin{array}{l}3 \\
4\end{array}$ & $\begin{array}{l}4 \\
9 \\
2\end{array}$ & $\begin{array}{l}6 \\
1 \\
2\end{array}$ & $\begin{array}{r}13 \\
9 \\
3\end{array}$ & $\begin{array}{l}3 \\
5\end{array}$ & $\begin{array}{r}14 \\
8 \\
20\end{array}$ & $\begin{array}{l}1 \\
1 \\
1\end{array}$ & $\begin{array}{l}2 \\
3\end{array}$ & 0 & 1 & & $\begin{array}{l}14 \\
38 \\
37\end{array}$ \\
\hline 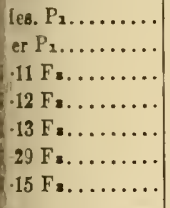 & & & & 1 & $\begin{array}{l}3 \\
1 \\
2\end{array}$ & $\begin{array}{r}15 \\
1 \\
9 \\
\\
12\end{array}$ & $\begin{array}{l}0 \\
0 \\
3 \\
1 \\
3\end{array}$ & $\begin{array}{r}15 \\
5 \\
19 \\
6 \\
3 \\
17\end{array}$ & $\begin{array}{r}9 \\
25 \\
12 \\
9 \\
14 \\
5\end{array}$ & $\begin{array}{l}2 \\
4 \\
0 \\
5 \\
3\end{array}$ & $\begin{array}{r}1 \\
1 \\
11 \\
15\end{array}$ & 2 & 7 & $\begin{array}{l}3 \\
1 \\
1\end{array}$ & 24 & 1 & 2 & 2 & $\begin{array}{l}41 \\
44 \\
37 \\
46 \\
36 \\
45 \\
42\end{array}$ \\
\hline 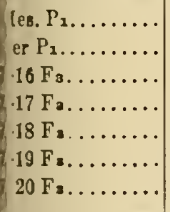 & & & & 1 & $\begin{array}{l}2 \\
3 \\
1 \\
0\end{array}$ & $\begin{array}{r}11 \\
3 \\
7 \\
7 \\
3 \\
2\end{array}$ & $\begin{array}{l}2 \\
2 \\
2 \\
1 \\
1 \\
1\end{array}$ & $\begin{array}{r}16 \\
3 \\
18 \\
8 \\
2 \\
3\end{array}$ & $\begin{array}{r}2 \\
18 \\
8 \\
18 \\
7 \\
13\end{array}$ & $\begin{array}{l}1 \\
0 \\
3 \\
4 \\
2\end{array}$ & $\begin{array}{r}1 \\
2 \\
1 \\
2 \\
15 \\
11\end{array}$ & \begin{tabular}{l|}
5 \\
\\
1 \\
2 \\
1
\end{tabular} & $\begin{array}{l}11 \\
\\
4 \\
4\end{array}$ & $\begin{array}{l}2 \\
\\
1 \\
1 \\
1\end{array}$ & $\begin{array}{r}14 \\
1\end{array}$ & 2 & 3 & & $\begin{array}{l}37 \\
35 \\
31 \\
38 \\
40 \\
39 \\
40\end{array}$ \\
\hline 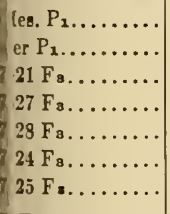 & & & 1 & $\begin{array}{l}2 \\
2\end{array}$ & $\begin{array}{l}1 \\
1 \\
4 \\
1 \\
1 \\
3\end{array}$ & $\begin{array}{l}9 \\
8 \\
4 \\
9 \\
3 \\
8\end{array}$ & $\begin{array}{l}6 \\
0 \\
0 \\
0\end{array}$ & $\begin{array}{r}11 \\
4 \\
8 \\
8 \\
10 \\
6\end{array}$ & $\begin{array}{r}10 \\
7 \\
4 \\
15 \\
14 \\
16\end{array}$ & $\begin{array}{l}2 \\
2 \\
1 \\
0 \\
1\end{array}$ & $\begin{array}{l}1 \\
7 \\
3 \\
5 \\
4 \\
1\end{array}$ & $\begin{array}{l}2 \\
0 \\
0\end{array}$ & $\begin{array}{l}3 \\
4 \\
5 \\
2 \\
2 \\
1\end{array}$ & $\begin{array}{l}1 \\
1 \\
0 \\
1\end{array}$ & $\begin{array}{l}20 \\
\\
2 \\
1\end{array}$ & 2 & 8 & 1 & $\begin{array}{l}35 \\
42 \\
38 \\
30 \\
40 \\
37 \\
37\end{array}$ \\
\hline $\begin{array}{l}\text { ies. } \mathrm{P}_{\mathbf{1}} \ldots \ldots \ldots \ldots \\
7 \mathrm{er} \mathrm{P}_{\mathbf{1}} \ldots \ldots \ldots \ldots \\
26 \mathrm{~F}_{\mathbf{s}} \ldots \ldots \ldots \ldots \\
2 \mathrm{~F}_{\mathbf{s}} \ldots \ldots \ldots \ldots \\
3 \mathrm{~F}_{\mathrm{a}} \ldots \ldots \ldots \ldots \\
4 \mathrm{~F}_{3} \ldots \ldots \ldots \ldots \\
5 \mathrm{~F}_{\mathbf{a}} \ldots \ldots \ldots \ldots\end{array}$ & & 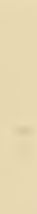 & 1 & 1 & $\begin{array}{l}1 \\
3\end{array}$ & $\begin{array}{r}16 \\
15 \\
6 \\
2\end{array}$ & $\begin{array}{l}2 \\
5 \\
2 \\
0\end{array}$ & $\begin{array}{r}19 \\
17 \\
3 \\
6 \\
8 \\
3\end{array}$ & $\begin{array}{r}3 \\
7 \\
9 \\
26 \\
14 \\
7\end{array}$ & $\begin{array}{l}2 \\
1 \\
2 \\
1 \\
1 \\
1\end{array}$ & $\begin{array}{r}12 \\
3 \\
5 \\
9\end{array}$ & $\begin{array}{l}1 \\
2 \\
2 \\
1\end{array}$ & $\begin{array}{l}10 \\
14 \\
12\end{array}$ & $\begin{array}{l}0 \\
2\end{array}$ & $\begin{array}{c}18 \\
1\end{array}$ & 0 & 5 & & $\begin{array}{l}34 \\
43 \\
49 \\
45 \\
45 \\
32 \\
33\end{array}$ \\
\hline 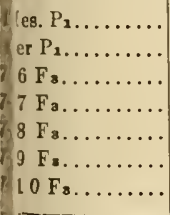 & & & $\begin{array}{l}2 \\
1\end{array}$ & $\begin{array}{l}1 \\
2\end{array}$ & $\begin{array}{l}1 \\
\\
1 \\
1 \\
5\end{array}$ & $\begin{array}{r}9 \\
0 \\
1 \\
9 \\
17\end{array}$ & $\begin{array}{l}0 \\
1 \\
1 \\
7\end{array}$ & $\begin{array}{r}17 \\
1 \\
5 \\
2 \\
14 \\
11\end{array}$ & $\begin{array}{r}16 \\
9 \\
15 \\
12 \\
3 \\
3\end{array}$ & $\begin{array}{l}0 \\
2 \\
6 \\
2 \\
1\end{array}$ & $\begin{array}{r}2 \\
12 \\
12 \\
4 \\
2\end{array}$ & $\begin{array}{l}4 \\
0 \\
2\end{array}$ & $\begin{array}{r}2 \\
12 \\
1 \\
7\end{array}$ & 1 & $\begin{array}{c}32 \\
1 \\
1\end{array}$ & 1 & 8 & & $\begin{array}{l}44 \\
45 \\
40 \\
40 \\
33 \\
39 \\
40\end{array}$ \\
\hline 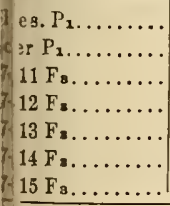 & & & 2 & $\begin{array}{l}2 \\
4\end{array}$ & $\begin{array}{l}6 \\
1 \\
4 \\
3 \\
6\end{array}$ & $\begin{array}{r}17 \\
6 \\
10 \\
6 \\
15 \\
1\end{array}$ & $\begin{array}{l}5 \\
5 \\
4 \\
\\
2 \\
2\end{array}$ & $\begin{array}{r}10 \\
12 \\
14 \\
17 \\
8 \\
4\end{array}$ & $\begin{array}{r}2 \\
12 \\
11 \\
17 \\
3 \\
20\end{array}$ & $\begin{array}{l}1 \\
4 \\
1 \\
1 \\
4\end{array}$ & $\begin{array}{l}2 \\
8\end{array}$ & 2 & 13 & 1 & 18 & 1 & 3 & 1 & $\begin{array}{l}37 \\
45 \\
41 \\
44 \\
44 \\
40 \\
44\end{array}$ \\
\hline
\end{tabular}


TABLE 30.-Continued.

\begin{tabular}{|c|c|c|c|c|c|c|c|c|c|c|c|c|c|c|c|c|c|c|}
\hline \multirow[b]{2}{*}{ Names of Strains } & \multicolumn{18}{|c|}{ Dates of Heading ( $1=$ June 26) } \\
\hline & 1 & 2 & 3 & 4 & 5 & 6 & 7 & 8 & 9 & 10 & 11 & 12 & 13 & 14 & 15 & 16 & 17 & 18 \\
\hline 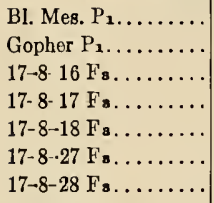 & & & 1 & 2 & 1 & $\begin{array}{r}28 \\
1 \\
8 \\
2\end{array}$ & $\begin{array}{l}6 \\
5\end{array}$ & $\begin{array}{r}10 \\
1 \\
10 \\
7\end{array}$ & $\begin{array}{r}1 \\
16 \\
16 \\
3\end{array}$ & $\begin{array}{l}6 \\
2 \\
2\end{array}$ & $\begin{array}{r}3 \\
1 \\
11 \\
2 \\
6\end{array}$ & \begin{tabular}{l|}
7 \\
3 \\
3 \\
3 \\
1
\end{tabular} & $\begin{array}{l}21 \\
14 \\
\\
13 \\
15\end{array}$ & $\begin{array}{l}3 \\
2 \\
2 \\
2 \\
3\end{array}$ & $\begin{array}{r}6 \\
4 \\
\\
9 \\
11\end{array}$ & $\begin{array}{l}1 \\
0\end{array}$ & $\begin{array}{l}1 \\
5 \\
1 \\
1\end{array}$ & $\begin{array}{l}3 \\
1\end{array}$ \\
\hline 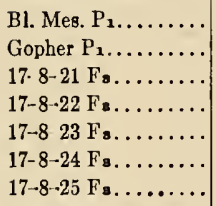 & & & & & $\begin{array}{l}4 \\
1\end{array}$ & $\begin{array}{l}4 \\
2 \\
6 \\
2\end{array}$ & $\begin{array}{l}0 \\
5 \\
3\end{array}$ & $\begin{array}{r}10 \\
1 \\
10 \\
5\end{array}$ & $\begin{array}{r}17 \\
9 \\
1 \\
8 \\
18 \\
15\end{array}$ & $\begin{array}{l}2 \\
1 \\
4 \\
2 \\
0 \\
1\end{array}$ & $\begin{array}{r}1 \\
14 \\
11 \\
10 \\
1 \\
6\end{array}$ & $\begin{array}{l}2 \\
1\end{array}$ & $\begin{array}{r}2 \\
\\
6 \\
15 \\
11 \\
\\
3\end{array}$ & 3 & $\begin{array}{l}9 \\
2 \\
3\end{array}$ & $\begin{array}{l}1 \\
1\end{array}$ & $\begin{array}{l}19 \\
1 \\
1\end{array}$ & 5 \\
\hline 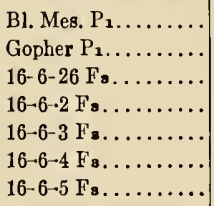 & & & 4 & 6 & $\begin{array}{l}11 \\
1\end{array}$ & $\begin{array}{l}9 \\
4 \\
2 \\
1\end{array}$ & $\begin{array}{l}1 \\
2\end{array}$ & $\begin{array}{r}7 \\
11 \\
10 \\
6\end{array}$ & $\begin{array}{r}23 \\
1 \\
3 \\
23 \\
18 \\
2\end{array}$ & $\begin{array}{l}2 \\
1 \\
5 \\
1 \\
3 \\
2\end{array}$ & $\begin{array}{r}2 \\
1 \\
14 \\
5 \\
12\end{array}$ & $\begin{array}{l}1 \\
1 \\
8\end{array}$ & $\begin{array}{l}15 \\
14\end{array}$ & $\begin{array}{l}3 \\
1\end{array}$ & $\begin{array}{l}11 \\
4\end{array}$ & 4 & 17 & 3 \\
\hline 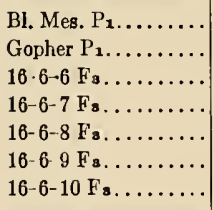 & & & $\begin{array}{l}2 \\
2\end{array}$ & 0 & $\begin{array}{l}1 \\
4 \\
2 \\
2\end{array}$ & $\begin{array}{r}5 \\
13 \\
1 \\
3 \\
5\end{array}$ & $\begin{array}{l}5 \\
0 \\
3 \\
3\end{array}$ & $\begin{array}{l}4 \\
9 \\
6 \\
5 \\
\\
3\end{array}$ & $\begin{array}{r}23 \\
5 \\
26 \\
8 \\
6 \\
7\end{array}$ & $\begin{array}{l}0 \\
3 \\
0 \\
0 \\
1\end{array}$ & $\begin{array}{l}2 \\
4 \\
3 \\
6 \\
2\end{array}$ & $\begin{array}{l}1 \\
0 \\
4\end{array}$ & $\begin{array}{r}5 \\
\\
5 \\
14 \\
2\end{array}$ & $\begin{array}{l}2 \\
1\end{array}$ & $\begin{array}{r}11 \\
1 \\
5\end{array}$ & 2 & 8 & 1 \\
\hline 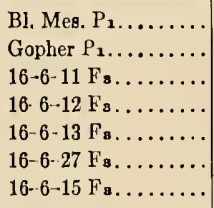 & & & & & $\begin{array}{l}2 \\
1\end{array}$ & $\begin{array}{r}11 \\
\\
1 \\
5 \\
12\end{array}$ & $\begin{array}{l}6 \\
\\
3 \\
2\end{array}$ & $\begin{array}{r}14 \\
2 \\
2 \\
8 \\
4 \\
11\end{array}$ & $\begin{array}{r}6 \\
1 \\
4 \\
19 \\
15 \\
13\end{array}$ & $\begin{array}{l}3 \\
4 \\
8 \\
1 \\
1 \\
0\end{array}$ & $\begin{array}{r}10 \\
16 \\
2 \\
5 \\
1\end{array}$ & $\begin{array}{l}1 \\
4 \\
0 \\
1\end{array}$ & $\begin{array}{r}11 \\
15 \\
7 \\
5 \\
6\end{array}$ & 2 & 18 & $\begin{array}{l}1 \\
2\end{array}$ & 4 & \\
\hline 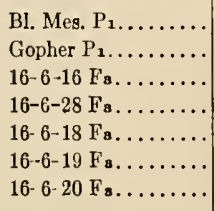 & & & & & $\begin{array}{l}7 \\
1 \\
1\end{array}$ & $\begin{array}{r}19 \\
2 \\
4 \\
\\
5\end{array}$ & $\begin{array}{l}3 \\
1\end{array}$ & $\begin{array}{r}11 \\
5 \\
11 \\
11 \\
1\end{array}$ & $\begin{array}{r}3 \\
18 \\
15 \\
\\
10 \\
14\end{array}$ & $\begin{array}{l}1 \\
1 \\
1 \\
1 \\
1 \\
1\end{array}$ & $\begin{array}{l}6 \\
7 \\
2 \\
7\end{array}$ & $\begin{array}{l}2 \\
2 \\
1 \\
7 \\
1\end{array}$ & $\begin{array}{l}22 \\
\\
4 \\
4 \\
9 \\
1 \\
9\end{array}$ & $\begin{array}{l}1 \\
1 \\
1 \\
1 \\
1\end{array}$ & $\begin{array}{r}4 \\
\\
16 \\
2\end{array}$ & $\begin{array}{l}5 \\
1\end{array}$ & 2 & 3 \\
\hline 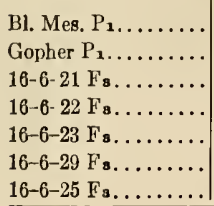 & & & 1 & 0 & $\begin{array}{l}0 \\
3 \\
3\end{array}$ & $\begin{array}{r}12 \\
1 \\
4 \\
12 \\
9\end{array}$ & $\begin{array}{l}7 \\
1 \\
1 \\
4\end{array}$ & $\begin{array}{r}11 \\
7 \\
1 \\
14 \\
16 \\
7\end{array}$ & $\begin{array}{r}11 \\
13 \\
14 \\
11 \\
12 \\
6\end{array}$ & $\begin{array}{l}3 \\
4 \\
7 \\
0 \\
5\end{array}$ & $\begin{array}{r}1 \\
7 \\
12 \\
3 \\
2 \\
11\end{array}$ & 2 & $\begin{array}{l}8 \\
7 \\
4\end{array}$ & 3 & 20 & 0 & 8 & 1 \\
\hline
\end{tabular}




\section{ABLE 30.-Continued.}

Dates of Heading ( $1=$ June 26)

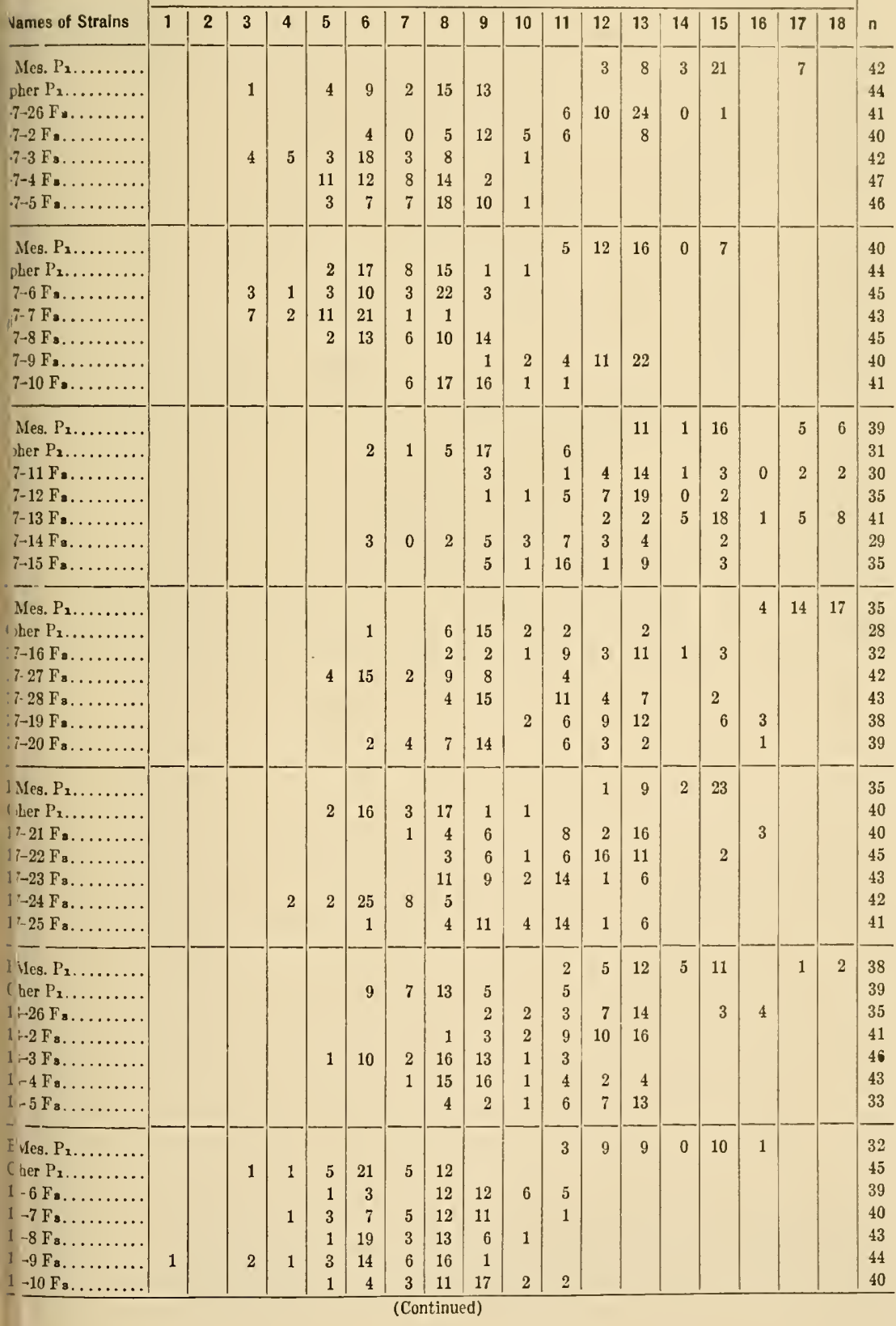


TABLE 31.-Concluded.

\begin{tabular}{|c|c|c|c|c|c|c|c|c|c|c|c|c|c|c|c|c|c|c|}
\hline \multirow[b]{2}{*}{ Names of Strains } & \multicolumn{18}{|c|}{ Dates of Heading $(1=$ June 26) } \\
\hline & 1 & 2 & 3 & 4 & 5 & 6 & 7 & 8 & 9 & 10 & 11 & 12 & 13 & 14 & 15 & 16 & 17 & 18 \\
\hline $\begin{array}{l}\text { Bl. Mes. P1....... } \\
\text { Gopher } \mathrm{P}_{1} \ldots \ldots \ldots \ldots \\
16-8-11 \mathrm{~F}_{\mathbf{8}} \ldots \ldots \ldots \\
16-8-12 \mathrm{~F}_{\mathbf{8}} \ldots \ldots \ldots \\
16-8-13 \mathrm{~F}_{\mathbf{z}} \ldots \ldots \ldots \ldots \\
16-8-14 \mathrm{~F}_{\mathbf{z}} \ldots \ldots \ldots \\
16-8-15 \mathrm{~F}_{\mathbf{8}} \ldots \ldots \ldots\end{array}$ & 1 & 1 & & 2 & $\begin{array}{l}1 \\
1 \\
2 \\
2\end{array}$ & $\begin{array}{l}7 \\
5 \\
2 \\
\\
4 \\
8\end{array}$ & $\begin{array}{l}5 \\
2 \\
\\
1 \\
4\end{array}$ & $\begin{array}{r}10 \\
11 \\
5 \\
5 \\
7 \\
3\end{array}$ & $\begin{array}{r}13 \\
23 \\
10 \\
16 \\
29 \\
6\end{array}$ & $\begin{array}{l}1 \\
0 \\
7 \\
3 \\
2 \\
3\end{array}$ & $\begin{array}{r}2 \\
3 \\
3 \\
18 \\
14 \\
\\
3\end{array}$ & $\begin{array}{l}1 \\
1 \\
1\end{array}$ & 8 & 1 & 23 & 3 & 5 & \\
\hline 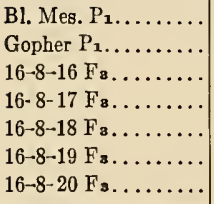 & & & 1 & 1 & 3 & $\begin{array}{r}18 \\
3 \\
16 \\
8\end{array}$ & $\begin{array}{l}2 \\
1 \\
3 \\
1\end{array}$ & $\begin{array}{r}12 \\
4 \\
7 \\
17\end{array}$ & $\begin{array}{r}8 \\
9 \\
13 \\
13\end{array}$ & $\begin{array}{l}1 \\
1 \\
5\end{array}$ & $\begin{array}{r}2 \\
14 \\
2 \\
11\end{array}$ & $\begin{array}{r}13 \\
2 \\
\\
5 \\
3\end{array}$ & $\begin{array}{r}11 \\
8 \\
\\
16 \\
5\end{array}$ & 0 & $\begin{array}{r}10 \\
2 \\
\\
6 \\
28\end{array}$ & $\begin{array}{l}1 \\
2\end{array}$ & 1 & 2 \\
\hline 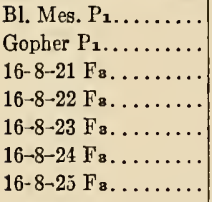 & & & $\begin{array}{l}1 \\
1\end{array}$ & $\begin{array}{l}1 \\
1\end{array}$ & $\begin{array}{l}2 \\
5 \\
2 \\
2 \\
1\end{array}$ & $\begin{array}{r}20 \\
12 \\
6 \\
13 \\
9 \\
10\end{array}$ & $\begin{array}{l}2 \\
3 \\
1 \\
1 \\
5 \\
6\end{array}$ & $\begin{array}{l}18 \\
12 \\
14 \\
18 \\
13 \\
15\end{array}$ & $\begin{array}{r}10 \\
16 \\
6 \\
7 \\
11\end{array}$ & 1 & $\begin{array}{l}2 \\
1 \\
4 \\
1 \\
3 \\
2\end{array}$ & 6 & 9 & 3 & 14 & & 1 & 1 \\
\hline $\begin{array}{l}\text { Bl. Mes. Px....... } \\
\text { Gopher Pr......... }\end{array}$ & & & & & 1 & 16 & 3 & 18 & 4 & & 1 & 7 & 6 & 5 & 16 & 2 & 2 & \\
\hline
\end{tabular}




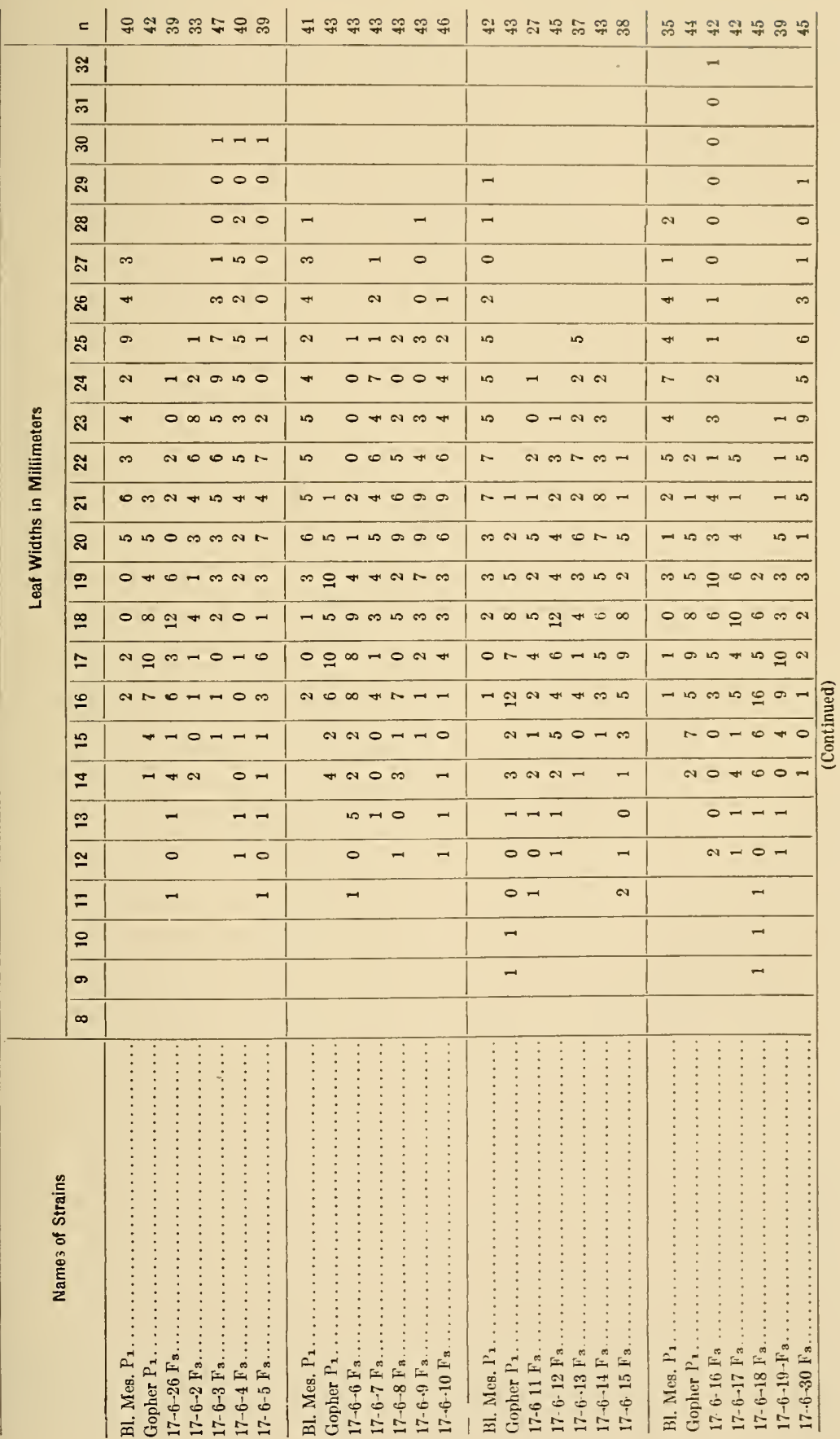




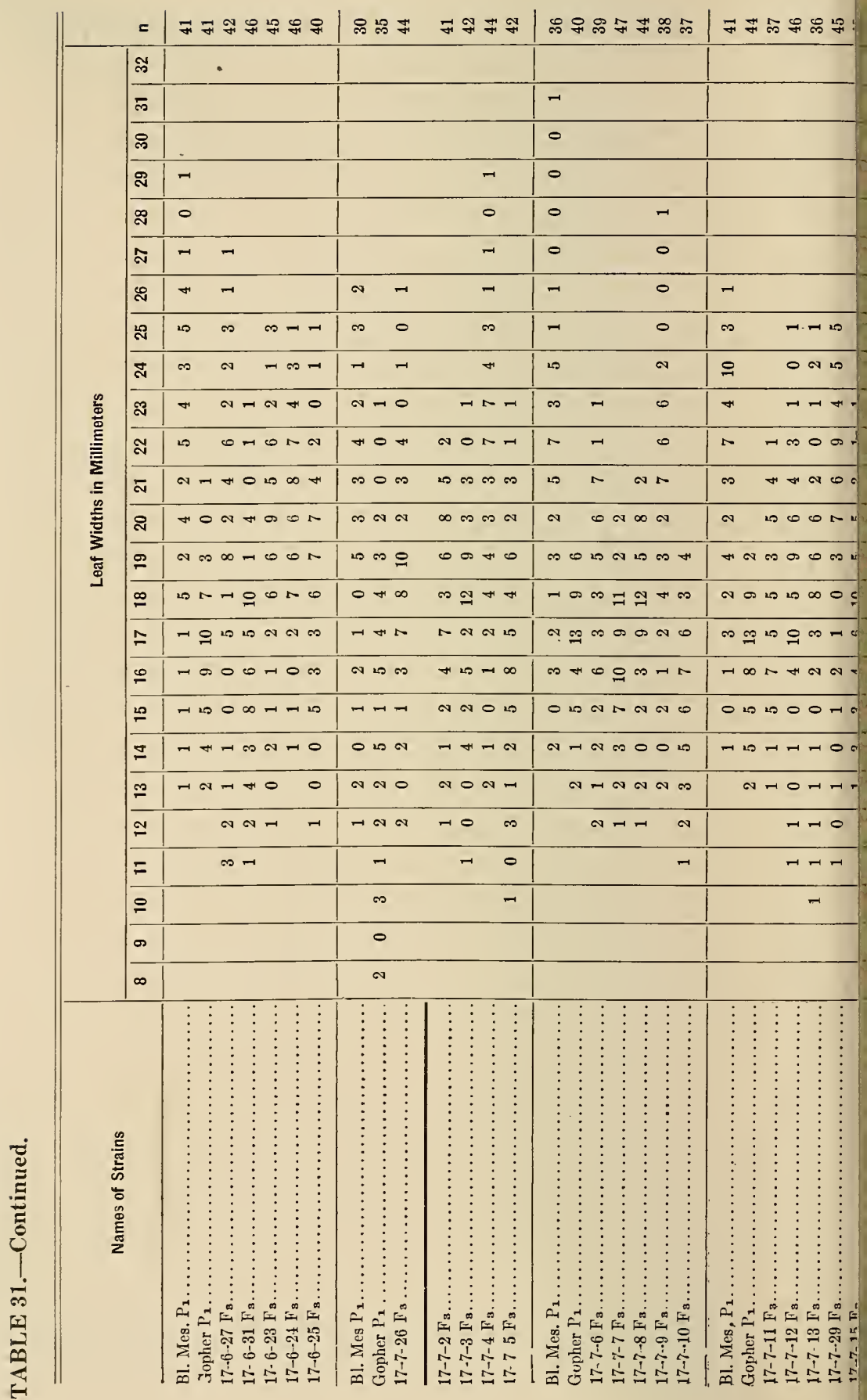




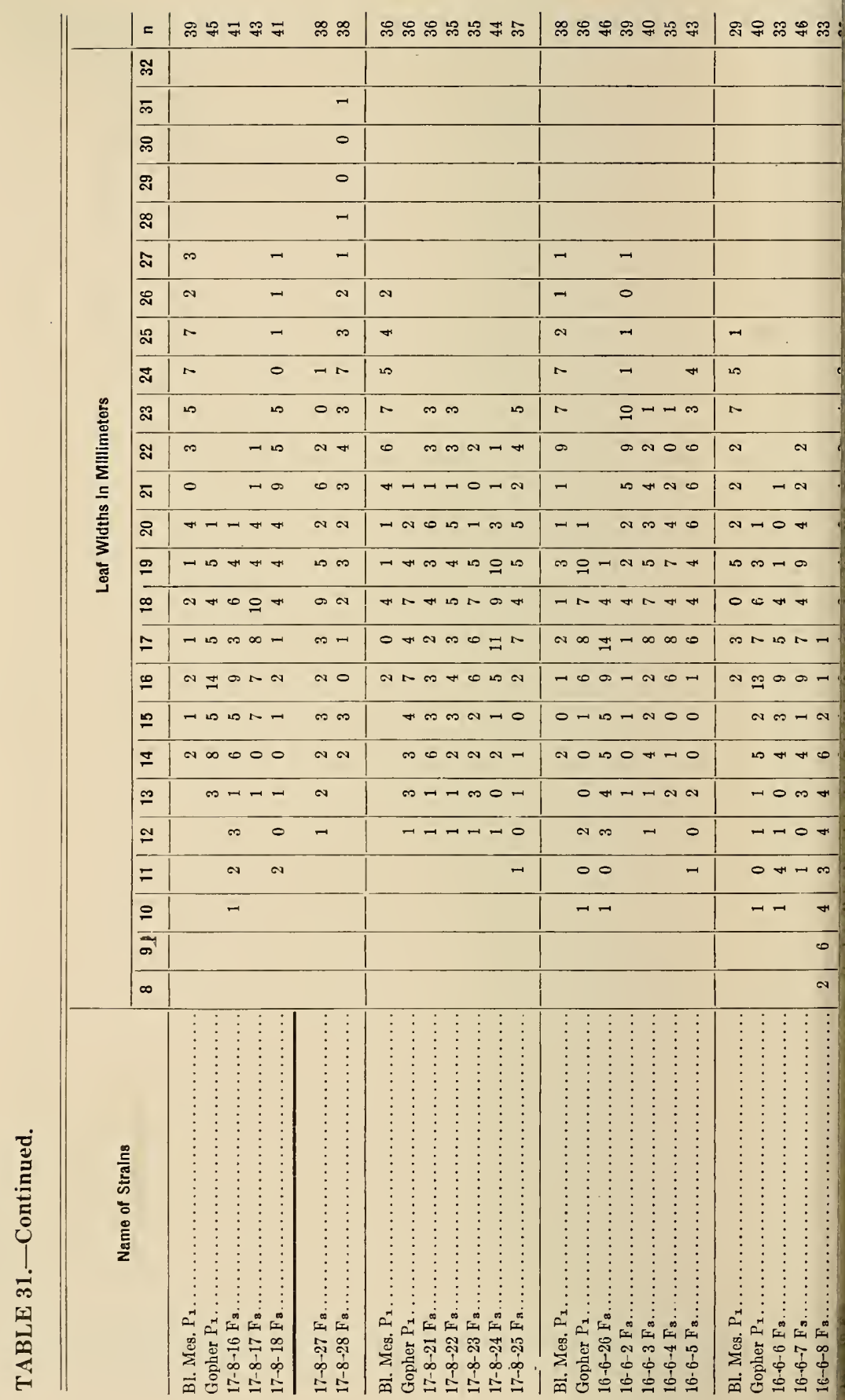




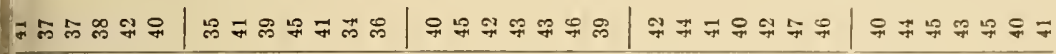

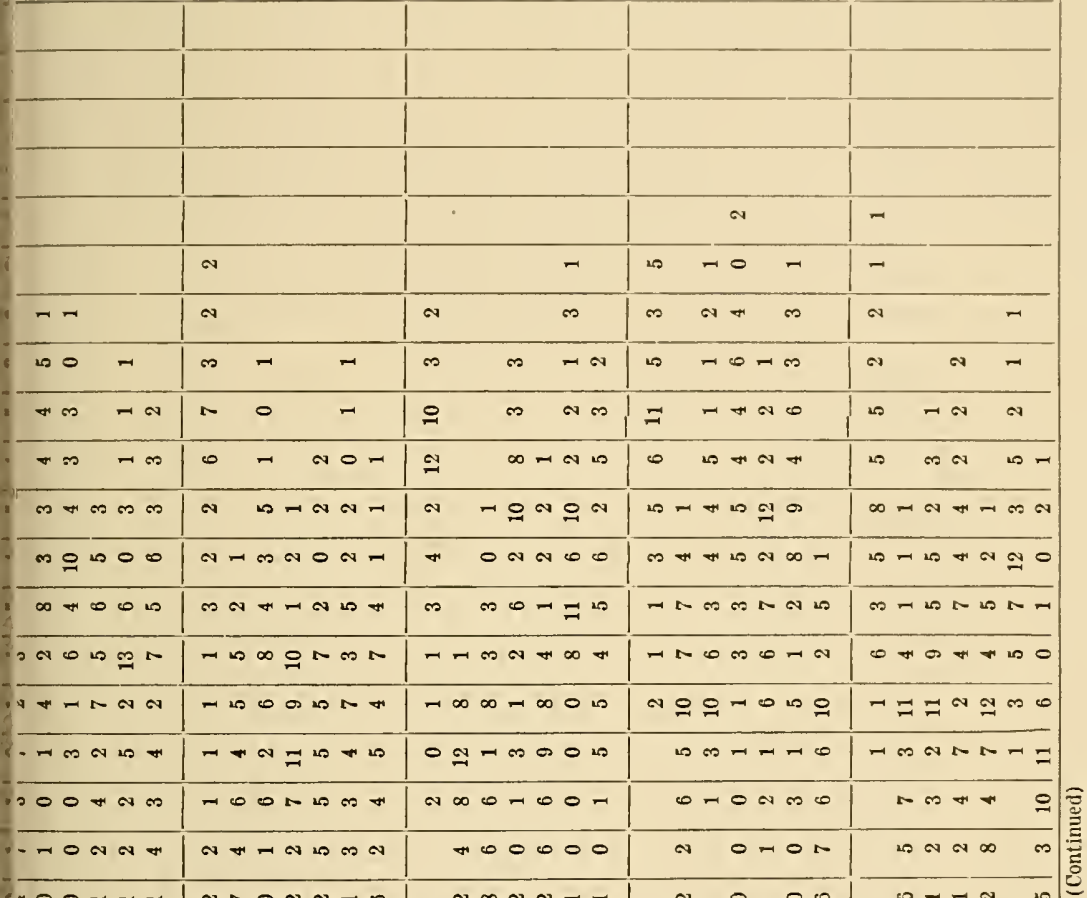

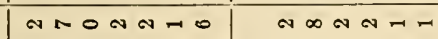

N 000

$0 \pi-\boldsymbol{n}$ a

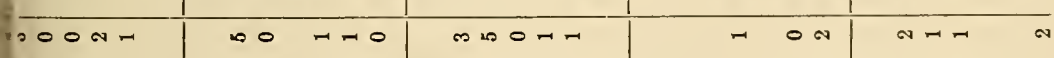

a $0-$

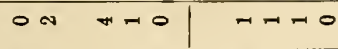

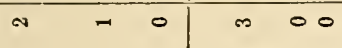

\begin{tabular}{|c|c|c|}
\hline$\pi-$ & $\infty$ & 0 \\
\hline & & 0 \\
\hline & & - \\
\hline
\end{tabular}




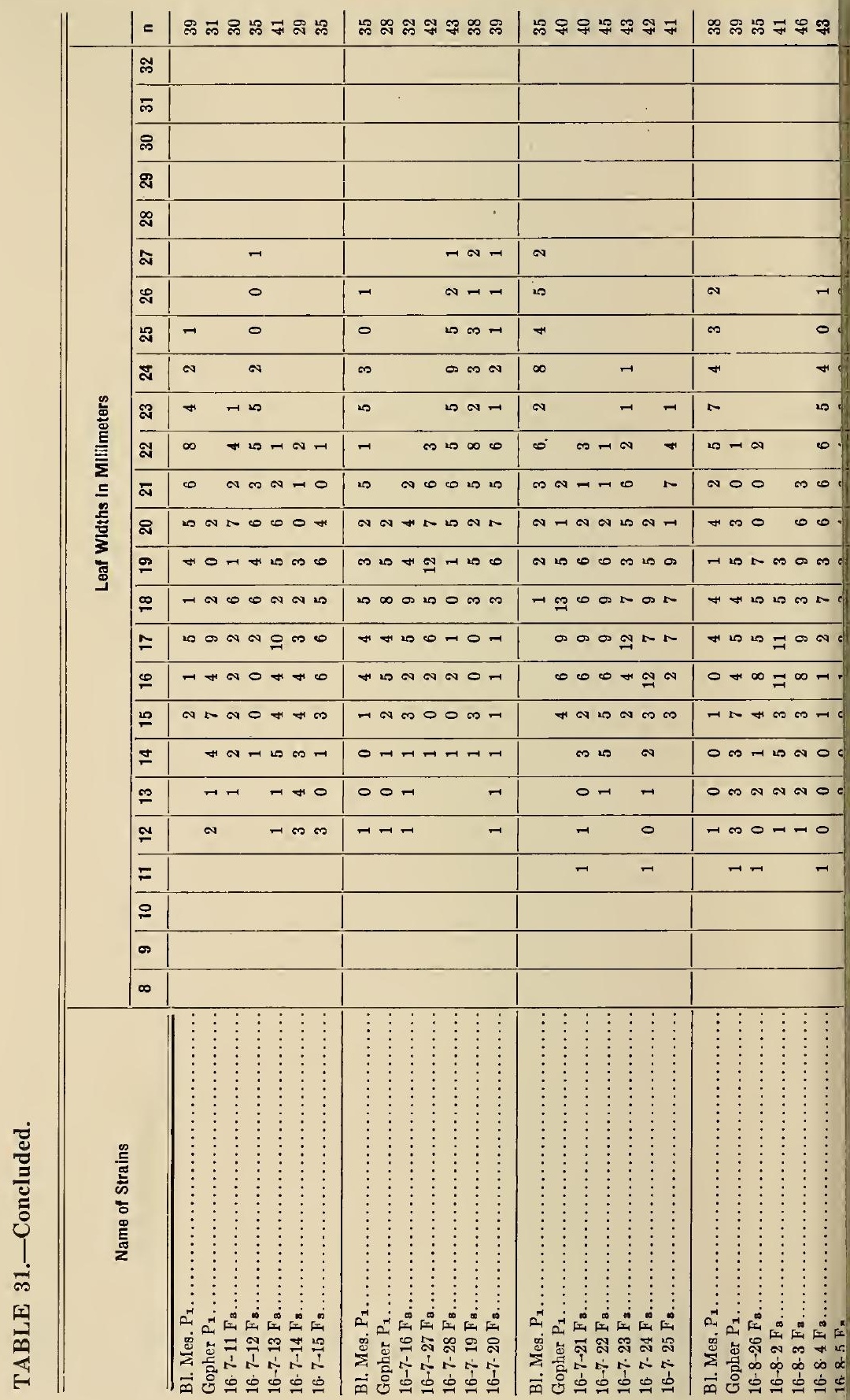




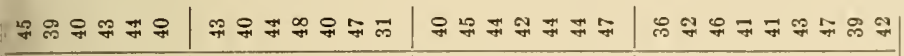

\begin{tabular}{l|l|l|l|}
\hline & \\
\hline
\end{tabular}

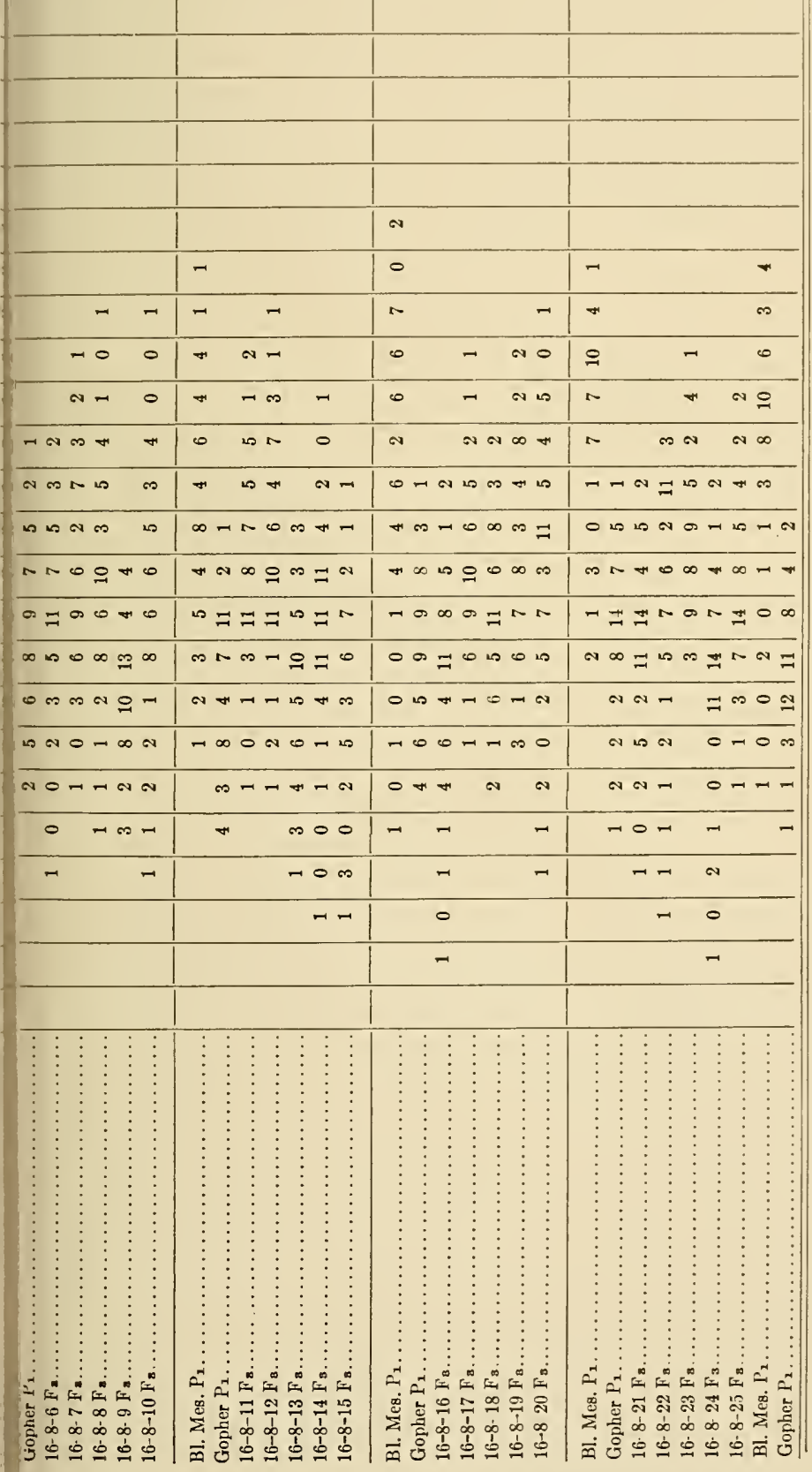





\section{HECKMAN}

BINDERY INC.

\section{JUNE 99}

N. MANCHESTER, 
